\title{
WIEJSKIE STRUKTURY OSADNICZE I ICH PRZEMIANY W CZASIE: PRZYKŁAD NOWOSIELCA NA DAWNYM POGRANICZU POLSKO-RUSKO-LITEWSKIM
}

\author{
RURAL SETTLEMENT STRUCTURES AND THEIR CHANGES OVER TIME. \\ THE EXAMPLE OF THE VILLAGE NOWOSIELEC ON THE FORMER \\ POLISH-RUS'-LITHUANIAN FRONTIER
}

\begin{abstract}
The article discusses the results of archaeological-onomastic research carried out for the village of Nowosielec, Łosice dist., situated in the Toczna river basin on the northern edge of Poland's Siedlce Upland. Archaeological analyses of the chronological and spatial development of this micro-regional settlement showed this oecumene to have been continuously viable from the younger phases of the early Middle Ages to modern times. A trace of the continuity of settlement is preserved as the very place-name Nowosielec $=$ Nowe Sioto ('New Village'), which records memory of the existence of an older village. Its onomastic base indicates that it derived from the Old East Slavic term seto, which formed the core of many toponyms along the eastern frontier of contemporary Poland. The rise of the oldest settlement was probably related to the socioeconomic facilities of the nearby Dzięcioły stronghold - identified as the pre-location centre of the region (medieval Losice). The example of Nowosielec and two other local micro-regions where settlement processes show similar patterns, offer insight into the regional settlement regress dated to the 2 nd half of the 13th century. Results of the research carried out in the upper Toczna river basin show that its cultural landscape radically changed not earlier than during the 14th-15th centuries and was not caused by a demographic decline. Regional cultural continuity between the early medieval, late medieval, and modern times can be identified thanks to archaeological investigations and linguistic analysis of regional toponyms - in the case of microregions continuously functioning from the early Middle Ages till the modern period derived from Old Russian apellatives and personal names.

KEY WORDS: cultural frontier, medieval Polish-Rus' frontier, medieval Polish-Lithuanian frontier, medieval settlement, early modern settlement, eastern Slavonic toponyms, toponomastic research, settlement changes during the early and late Middle Ages
\end{abstract}

\section{WSTĘ}

Średniowieczne i wczesnonowożytne osadnictwo pogranicza Mazowsza i północno-wschodniej Małopolski z Rusią Halicko-Włodzimierską, a następnie z Litwą na terenie dorzecza środkowego Bugu stanowi temat podejmowany przez humanistów od blisko stu lat ${ }^{1}$. Problematyka ta pojawiła się jeszcze

1 Podstawę historyczną do tego typu studiów, wykorzystywaną zarówno w zakresie syntez, jak też analitycznych studiów mikroregionalnych, stanowią opracowania, 
w okresie międzywojennym, pozostając odtąd domeną eksplorowaną przez archeologów, historyków i językoznawców (m.in. Makarski 1996; Nalepa 2000; Gałecki 2014 - tam literatura). Szczególnie intensywnie prace te podejmowane były na gruncie archeologicznym, zarówno w zakresie analitycznych studiów mikroregionalnych (np. Kalaga 1989; Miśkiewicz 1996; Wróblewski 2001), jak też ujęć syntetycznych (Jakimowicz 1935; Musianowicz 1960; Miśkiewicz 1981).

Studia te z założenia obejmowały jednak wyłącznie wczesnośredniowieczny etap rozwoju kulturowego regionu. W efekcie, w sferze analiz archeologiczno-historycznych ugruntował się pogląd o regresie osadniczym i demograficznym, który miał nastąpić tam około 2. połowy XIII stulecia i stanowić cezurę oddzielającą tę fazę od późnego średniowiecza. Jego przyczyn upatrywano najczęściej w najazdach jaćwiesko-litewskich i tatarskich, jakie wielokrotnie odnotowane zostały w źródłach pisanych (np. Włodarski 1958; 1959; Tyszkiewicz 1974; 2003, 80-82; Suchodolska 1994, 182-183; Miśkiewicz 1981, 116; 1996, 76; Świętosławski 1997; Wróblewski 2001, 215 , 217-219), a także trwających już od ostatniej ćwierci XII w., polsko-ruskich sporach terytorialnych, przeradzających się niejednokrotnie w konflikty zbrojne (Wilkiewicz-Wawrzyńczykowa1937;Włodarski1966, 166-167,193-194;1969;1971,19-21;Kotkowicz2013). Faza późnośredniowieczna charakteryzowała się już odmiennym rytmem rozwoju kulturowego, generującego inny od wczesnośredniowiecznego obraz archeologiczny. Wspierało to tezę o zniszczeniu starszej sieci osadniczej, którą w późnym średniowieczu zastąpiły struktury reprezentujące całkowicie odmienny schemat administracyjno-gospodarczy.

Prezentowane studium jest próbą wyjścia poza standardy polegające na rozdzielnym traktowaniu faz osadniczych wczesnego i późnego średniowiecza. Najnowsze badania prowadzone na terenie dorzecza środkowego Bugu sukcesywnie falsyfikują bowiem podstawy koncepcji zakładającej istnienie głębokiego regresu osadniczego, rozdzielającego obydwa te okresy. Zarówno badania historyczne, jak i archeologiczne nie pozostawiają wątpliwości w zakresie kontynuacji funkcjonowania głównych grodów regionu: Drohiczyna, Mielnika oraz bezpośrednio związanego z nimi - Bielska. Miały one u schyłku wczesnego śre-

które powstały jeszcze w 1. połowie XIX w. (M. Baliński, T. Lipiński 1846, s. 721-800; 1886, s. 330-331, 400-464) oraz w 2. połowie tego samego stulecia i na początku XX w. (SG; ŹDz. XVII). dniowiecza charakter prężnie rozwijających się ośrodków proto-miejskich, który w XV w. potwierdziły najstarsze w regionie przywileje lokacyjne (Drohiczyn: Musianowicz 1969; Pawlata 2014; Mielnik: Michaluk 1999; Andrzejewska 2008; Bielsk: Zieleniewski 1990; Mazuruk 2004). W 2. i 3. ćwierci XIII w. w ośrodkach tych powstały najstarsze murowane cerkwie. Tę samą metrykę może mieć również funkcjonujący w późnym średniowieczu i we wczesnej nowożytności manastyr św. Spasa w Drohiczynie (Skrzyńska 2019d, 276 - tam literatura).

Śladów wyraźnego regresu nie obserwuje się także w odniesieniu do struktur osadniczych o charakterze wiejskim. Sugestywnie obrazują to wyniki badań prowadzonych na cmentarzyskach z grobami w obstawach kamiennych. Dolną granicę chronologiczną użytkowania tych nekropoli tradycyjnie osadzano w XIII w., umacniając tezę o braku kontynuacji tradycji kulturowych wczesnego średniowiecza w XIV-XV w., a tym bardziej w fazie wczesnonowożytnej (Rauhut 1971, 474; Miśkiewicz 1981, 101102). Dopiero badania Michała Dzika (2012,733-739) wykazały, że cmentarze te nie zostały porzucone. Przeciwnie - te z nich, które szerzej rozpoznano archeologicznie, charakteryzuje ciągłość użytkowania datowana co najmniej do XV w. Co więcej, cmentarze $\mathrm{z}$ grobami, których konstrukcje symbolicznie nawiązywały do wczesnośredniowiecznych obstaw, powstawały i funkcjonowały w dorzeczu środkowego Bugu jeszcze w XVI i XVII stuleciu (Dzik 2011; Krasnodębski, Skrzyńska, Olczak 2019, 44, 53). Podobne spostrzeżenia poczyniono dla tradycji kurhanowej, która w formie silnie zmodyfikowanej przez wdrażanie wymogów cerkiewno-kościelnych i zredukowanej do rangi symbolu przetrwała $\mathrm{w}$ regionie do wczesnej nowożytności (Skrzyńska 2018).

Obserwacje przeprowadzone w szerszej perspektywie regionalnej ${ }^{2}$ wspierają powyższe ustalenia. Wyniki analizy dokumentacji AZP i sporządzona na ich podstawie mapa osadnictwa obrazująca przemiany i ciągłość zasiedlenia w XIII w. nie wskazuje na załamanie się jego struktury w tej fazie (Skrzyńska - materiały niepublikowane). Nie potwierdzają tego również badania weryfikacyjne, przeprowadzone punktowo na terenie wybranych mikroregionów osadniczych z dobrze udokumentowaną fazą trwałego zagospodarowania we wczesnym średniowieczu (Krasnodębski, Skrzyńska, Olczak 2019, 39-53;

2 Południowa część dorzecza środkowego Bugu oraz międzyrzecze środkowego Bugu i górnej Narwi. 
por też Jaskanis 2008, 25-39). Podobny wynik dały, ukierunkowane na zbadanie tej kwestii, prospekcje weryfikacyjne przeprowadzone w szerszym kontekście przestrzennym, obejmującym obszar $110 \mathrm{~km}^{2}$ dorzecza górnej Tocznej - jednego z większych lewobrzeżnych dopływów środkowego Bugu (Skrzyńska, Bryńczak 2019). Analiza pozyskanej ceramiki, połączona z kartowaniem punktów osadniczych w ramach wydzielonych faz rozwoju osadnictwa, wykazała, że gwałtowna zmiana, połączona z porzuceniem większości starych osad nastąpiła tam dopiero w XIV stuleciu. Proces ten przebiegał równolegle do rozpoczętej wówczas kolonizacji tego obszaru, co stało się dobrze czytelne dla XV w. (Gieysztor 1967, 24; Russocki 1972, 227; Jaszczołt 2013). Postępowała ona na tyle szybko, że archeologiczne wydzielenie kolejnych jej etapów, w obecnym stanie rozpoznania regionu, nie jest możliwe. Rysuje się ona więc jako kompleksowy epizod, którego obecność jest wynikiem złożonego strukturalnie procesu, opartego na wielokierunkowej migracji ludności o polskiej (głównie mazowieckiej i małopolskiej), ruskiej (głównie nadniemeńskiej i wołyńskiej) oraz o litewskiej tożsamości etnokultu- rowej (por. Wiśniewski 1964). Weszła ona zapewne w bezpośredni kontakt ze społecznością lokalną - jak wykazały badania archeologiczno-historyczno-onomastyczne w dorzeczu górnej Tocznej, zasiedlając tereny dotąd niezagospodarowane, pozostające poza zasięgiem nadal funkcjonujących ,autochtonicznych” ekumen (Skrzyńska, Bryńczak 2019, 121-122, 125).

Stan rozpoznania problematyki badawczej związanej z kontynuacją wczesnośredniowiecznych tradycji osadniczych wciąż pozostaje na etapie wstępnego rozpoznania. Najnowsze wyniki badań uzasadniają jednak potrzebę postawienia nowej tezy, zakładającej, że przemiany w strukturze i formie zasiedlenia regionu na progu wczesnego i późnego średniowiecza miały miejsce przy zachowaniu ciągłości osadniczej i nie towarzyszył im, jak zakładano do niedawna, głęboki regres demograficzny.

Sytuację tę w mikroskali obrazuje przykład wsi Nowosielec administracyjnie przynależącej do gminy i powiatu Łosice, stanowiących wschodnią część współczesnego województwa mazowieckiego. Istnieje ona co najmniej od 1. połowy XV w., funkcjonując na zapleczu osadniczym lokacyjnych Łosic, w odle-

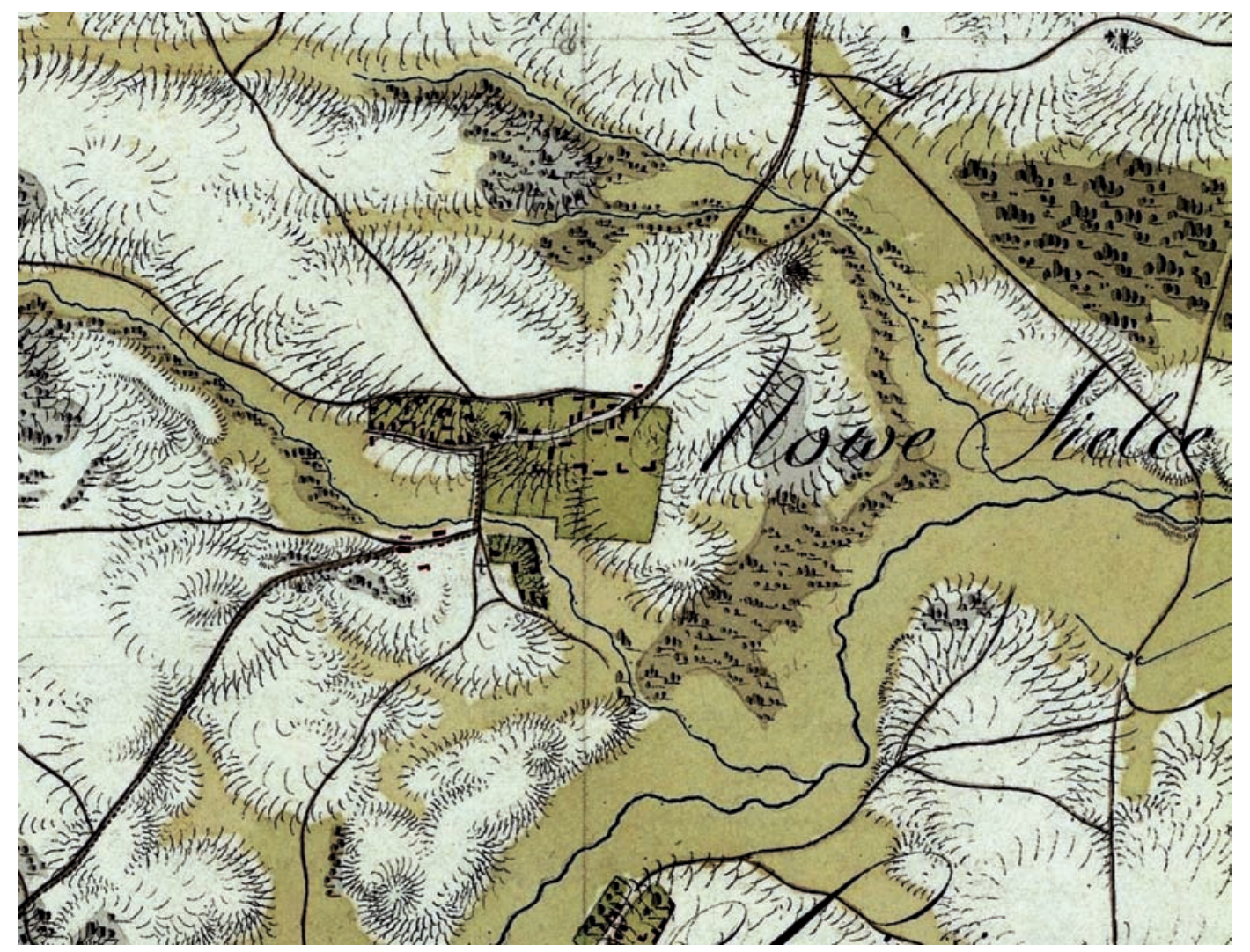

Ryc. 1. Wieś Nowe Sielce (wsp. Nowosielec, gm. Łosice) na początku XIX w.

(A. M. von Heldensfeld 1804, kol. XVII, sekcja 225)

Fig. 1. Nowe Sielce village (modern Nowosielec, Łosice dist.) at the beginning of the 19th century

(A. M. von Heldensfeld 1804, col. XVII, section 225) 
głości 3,5 km na północ od współczesnego miasta. Miejscowość ta usytuowana jest pomiędzy dwoma niewielkimi strumieniami, wpadającymi do górnej Tocznej, mającej swe źródła w północnej części wysoczyzny siedleckiej (ryc. 1). Ustalenia onomastyczno-historyczne dotyczące inicjalnej fazy rozwoju wsi, połączone z wynikami powierzchniowej prospekcji archeologicznej, dały interesujący rezultat, będący przykładem efektywności współpracy interdyscyplinarnej, podejmowanej w zakresie badań humanistycznych ${ }^{3}$.

\section{NOWOSIELEC W ŚWIETLE DANYCH ONOMASTYCZNO-HISTORYCZNYCH}

Pierwsza wzmianka o miejscowości pochodzi z 1448 r., kiedy to "szlachetny Jakub de Nowosielce" otrzymał wójtostwo w pobliskich Niemojkach (Dobrowolski 2019, 107). Kolejne zapisy jej nazwy notowane były $\mathrm{w}$ formie podstawowej oraz obocznych w okresie od XVI do 1. ćwierci XX w.: 1528 r. - „Nowoselcy zemiane" (ŹDz XVII/1, 186: forma starobiałoruska w dokumencie błrus.); ok. 1560 - „Michał Znowosielca" (Inwentarz - AGAD, ASK, LVI, M2, I - k. 203 [Komornicy Miasta Łosickiego]; 1580 r. „Nowosielcze, Zakrze, Pathkowicze, urodzony Piotr Patkowski, sędzia ziemski mielnicki, dał $\mathrm{z}$ imion swych Patkowic, Zakrza, z włók osiadłych 81/2, po złotemu" (ŹDz XVII/1, 64 [Parochia Łosicka]); 1626 - Nowosielec (SHG Pd; MK nr 174, k. 36-36v); 1662 - Wies Nowosielecz (Akty 419); 1676 - Nowosielec (SHG Pd [Rejpogł]); 1795 - Nowo Sielce (MpPerPd); 1801-1804 - Nowe Sielce/Nowosielce (Heldensfeld, kol. XVII, sekcja 225); 1827 - Nowosielce (Tabella II, 52); 1839 - Nowosielec (MpKwat VI 7); 1859 - Nowocielce [!] (MpChrzan ark. XX); 1886 - Nowosielec (SG VII, 273); 1921 - Nowosielce (Sk IV, 46). Dopiero po II wojnie światowej nazwa Nowosielec ustalona została urzędowo w formie 1. pojedynczej (1971 - Nowosielec, Nowosielca [dopełniacz], nowosielecki [przymiotnik]: UNłos, 21).

3 W artykule zaprezentowano wyniki badań stanowiących suplementarny efekt realizacji projektu badawczego pt. Przemiany osadnicze w dorzeczu górnej Tocznej we wczesnym i późnym średniowieczu, finansowanego ze środków Ministerstwa Kultury i Dziedzictwa Narodowego w latach 2018-2019 (nr 4319/18/FPK/NID) oraz z dotacji celowej Burmistrza Miasta i Gminy Łosice.
Kolejne wzmianki dotyczą nazwiska Nowosielski, które jest pierwotnym przymiotnikiem utworzonym od nazwy miejscowości w znaczeniu: „właściciel Nowosielca, pochodzący z Nowosielca". Szczegółowe badania historyczne dowiodły, że miejscowość ta od XV w. do lat dwudziestych XIX w. stanowiła siedzibę Nowosielskich herbu Ślepowron, należących do znaczniejszych rodów ziemi mielnickiej (Dobrowolski 2019, 39-40). Nazwisko poświadczone jest źródłowo w 1497 r., a w postaci Nowosiedlski (z nieuproszczoną grupą spółgłoskową -dlsk-) w $1498 \mathrm{r}$. i jest zasadnie wyprowadzane od nazw miejscowych Nowe Sioło, Nowosielce [kilka wsi]; (Rymut NP II, 164).

Wyraz sioło ('wieś, wioska, osada wiejska') jest natomiast częściowo spolonizowaną postacią staroruskiego określenia seło, odnotowanego już w latopisach z początku XII w. (por. współczesne błrus. сял'o, ukr. сел'o, ros. сел'o, сельский 'wiejski', посёлок 'osiedle, osada', które pochodzą z prasłowiańskiego *sedlo 'wieś', tak samo jak stpol. siodło [z przegłosem psł. ${ }^{*} e>o$ i zachowaniem grupy $\left.\left.-d t-\right]\right)$.

Wschodniosłowiańskie uproszczenie grupy $-d t$ dokonało się jeszcze w dobie prasłowiańskiej, w dialekcie wschodnioprasłowiańskim (por. np. myło, ale pol. mydło, czes. mýdlo itd.). W języku staropolskim siodło poświadczone jest tylko w znaczeniach: 1. 'rodzaj siedzenia zakładanego na zwierzę do jazdy wierzchem' i 2. 'stołek' (SStp VIII, 206), ale znaczenie ,gospodarstwo kmiece z zabudowaniami mieszkalnymi i gospodarskimi, też rola należąca do gospodarstwa, dom”, czyli ogólnie biorąc „siodło” w znaczeniu etymologicznym, przejął nowszy wyraz siedlisko (siadlisko, sielisko); (SStp VIII, 177-179), derywat od siodta spokrewnionego z siedzieć. W materiałach Słownika staropolskiego siedlisko jest poświadczone licznymi przykładami ze źródeł z całego polskiego obszaru etnicznego (ryc. 2). Kilka przykładów polsko-ruskiej formacji słowotwórczej siedliszcze i sieliszcze (z grupą -dl- i sufiksem -iszcze), zapisanych na obszarze języka białoruskiego i ukraińskiego, pochodzi z „Kodeksu dyplomatycznego katedry i diecezji wileńskiej”, z „Akt grodzkich i ziemskich” z Archiwum tzw. bernardyńskiego we Lwowie, z „Kodeksu dyplomatycznego Polski" (SStp VIII, 179). Jeden zapis siolo z 1461 r. w dokumencie z Biblioteki Ossolińskich we Lwowie, ,zapewne jako nomen proprium” (SStp VIII, 207), wskazuje na staroruskie pochodzenie. Ruski rodowód sioła i form pokrewnych sielski, sielan$k a$ 'wieśniaczka' stwierdzają Aleksander Brückner, Halina Turska, Stanisław Urbańczyk i inni badacze. 


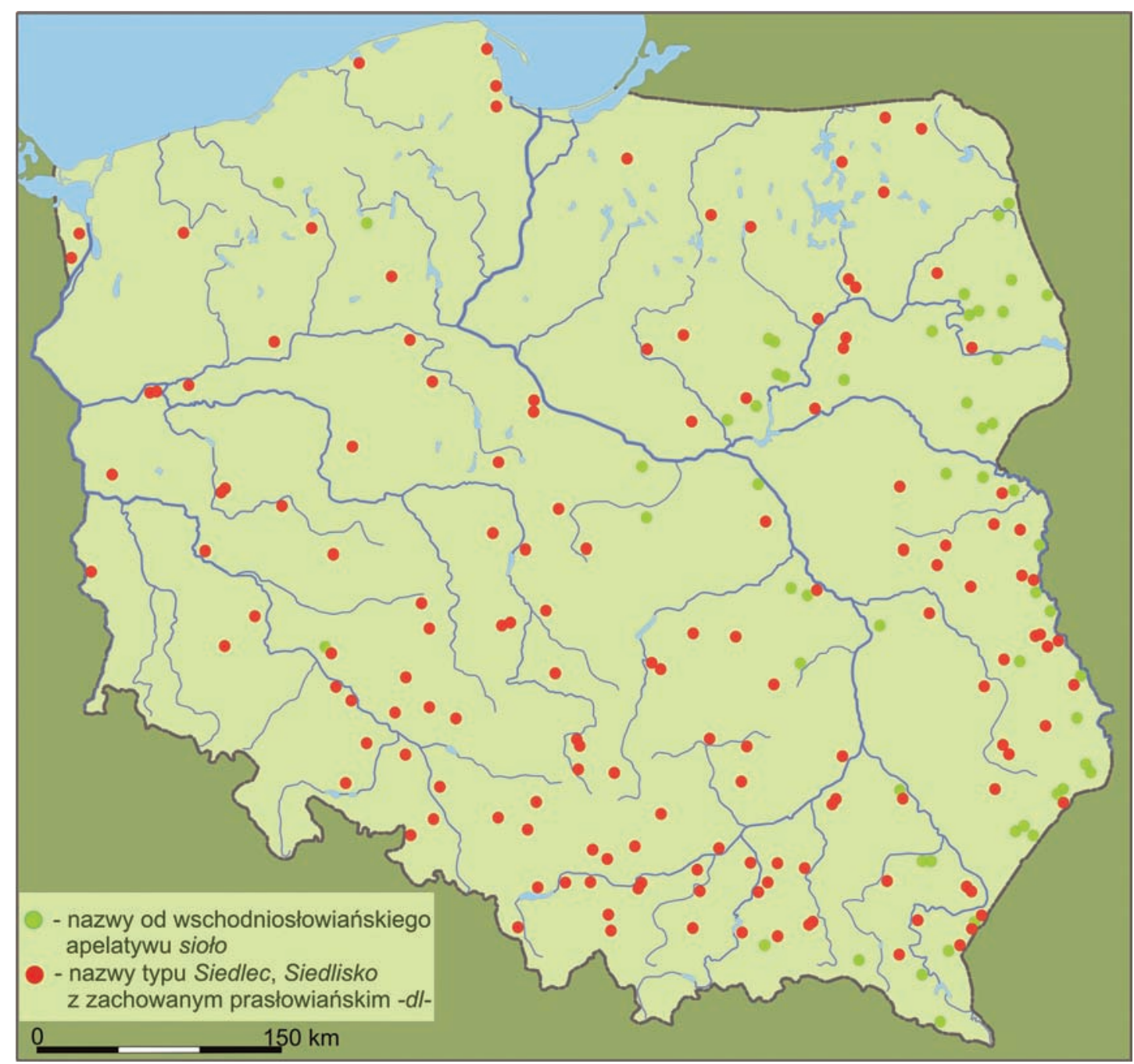

Ryc. 2. Rozmieszczenie nazw miejscowych Nowosielec, Nowosielce Nowosiółka i Nowosiótki na terenie Polski na tle nazw miejscowych typu Siedlce, Siedlec, Siedlisko, Siedliszcze. Mapa poglądowa* (oprac. K. Skrzyńska) Fig. 2. Distribution of place names Nowosielec, Nowosielce Nowosiótka and Nowosiótki in Poland in the context of toponyms Siedlce, Siedlec, Siedlisko, Siedliszcze. Schematic map (prepared by K. Skrzyńska)

* Z wyjątkiem przykładów przytoczonych w tekście i tytułowego Nowosielca, pow. Łosice, geneza pozostałych nazw miejscowych nie była dokładnie analizowana.

H. Turska wskazuje dwa niezależne źródła - ukraińskie i białoruskie. Sioło należy do tej warstwy zapożyczeń ze staroukraińskiego, co bachmat, chomik, dolina ,jar, parów”, klacz, koniuch „pasterz koni”, krynica, sterta, które stały się wyrazami ogólnopolskimi, zrobiły „karierę” w języku literackim (Urbańczyk 1968, 302). Dla XVI w. określenie to rejestrowane jest już nie tylko u autorów kresowych. W XIX w. zaktualizowane zostało przez literaturę romantyczną (szkoła ukraińska); (Minikowska 1980, 108-109). Wiesław Boryś $(2005,548)$ o siole napisał z pewną rezerwą: „postać może przejęta ze wschsł., na rodzime *siodło wskazują wcześnie poświadczone nazwy miejscowe typu Siedlno, Siedlec, Siedlce..." (por. też. stpol. siodtak 'chłop', n.m. Dtugosiodto).
Bywa też tak, że w warstwie nazewniczej zachowuje się „stare sioło”, natomiast „nowe” otrzymuje inną nazwę. Modelowym przykładem jest nazwa miejscowa Starosielce określająca część miasta Białegostoku. Jej najstarsze poświadczenie filologiczne pochodzi z 1580 r. Michał Kondratiuk $(1974,190)$ wyjaśnił ją jako nazwę kulturową pochodzącą od stare sielce : siedlce, tj. 'stara wieś, siedziba'. Odwrotną sytuację notujemy w przypadku Siedlec, gdzie starsza miejscowość straciła swoją nazwę na rzecz młodszej, stając się Starą Wsią (Wojciechowski et al. [oprac.] 1986, 137). W 1. połowie XV w. (1441 r.) były to jeszcze Siedlce, odnotowane jako Sedlecze (pf. Łuków), następnie jako Szedlecz (1448 r.), Shydlcze (1459 r.), wieś Syedlcze (1529 - pf. Pruszyn) i 1531; w 1532 r. 
erygowano parafię Siedlce. Po lokacji miasta, sąsiadującą z nim starą wieś parafialną zaczęto nazywać Starą Wsią: Siethlcze Stara Wiess - 1564 (kościół parafialny położony był za miastem ad pagum Starowies: 1595) - jej śladem jest ulica Starowiejska (przejściowo $\dot{Z} y$ mierskiego). Dopiero WUN III na s. 303 notuje Starq Wieś jako część miasta Siedlce.

Nazwy miejscowości Nowosielce w 1. mnogiej (za: NMPol. VII, 528-529), które można wywieść od podstawy sioło, występują tylko na wschodnich i południowo-wschodnich pograniczach ziem polskich (ryc. 2) ${ }^{4}$. Są to np.: Nowosielce - wieś zaginiona k. Tomaszowa Lubelskiego, w przypadku której wszystkie zapisy, poczynając od 1469 r. po ostatni w 1662 r., mają postać Nowosielce, a czasem obocznie: Nowosiótki (1557, 1565); Nowosielce - wieś w pow. przeworskim o zapisach historycznych: Nowosiedlce $(1372,1495)$, Nowosiedlec (1391), późniejsze zapisy w postaci Nowosielce, Nowosielec; Nowosielce - wieś w pow. sanockim, gm. Zarszyn, w przypadku której pierwsze zapisy są po polsku z -dl-: Now(e)(o)siedlce (1390, $1425,1439,1454,1457,1512)$, a późniejsze już w postaci Nowosielce (1665, 1794 itd.), natomiast pierwszy zapis nazwy po ukraińsku to „y Новосёльиехъ” (1390) [u Nowosělcechъ]; Nowosielce Kozickie - wieś w gm. Ustrzyki Dolne: Nowosiedlce (1417), Nowosielce (1785).

\section{NOWOSIELEC - ARCHEOLOGICZNA REKONSTRUKCJA MIKROREGIONU OSADNICZEGO}

Z perspektywy onomastycznej nazwa Nowe Sioto zakłada istnienie starszego punktu osadniczego, tj. jakiegoś „starego sioła”. Określenia stare - nowe sioło musiały wchodzić w opozycję realną (desygnat, miejsce zasiedlone, sioło, osada) i w opozycję językową (nazewniczą), co właśnie jeszcze dziś wyraża się w nazwie Nowosielec. W materiałach onomastycznych dorzecza Tocznej nie zachowała się jednak nazwa miejscowa, która stanowiłaby adekwatny

4 Na tym samym terenie notowanych jest też kilkanaście starych nazw w postaci Nowosiótki. Oprócz nazw dwóch nowych miejscowości: Nowosiółka w gm. Iłża (część wsi Nowa Jedlanka, dawniej wieś - NMpol VII, 529) oraz Nowosiółki w gm. Nowe Miasto (NMPol VII, 530) - ich rozmieszczenie zamyka się w pasie średniowiecznego i wczesnonowożytnego polsko-ruskiego pogranicza etnokulturowego. człon opozycyjny, semantycznie łączący się z poprzedzającym powstanie Nowosielca starym siołem. Nie mniej jednak, obydwa warianty stanowią typy nazw kulturowych pozostających ze sobą w bezpośredniej relacji znaczeniowej (Nowosielec - *Starosielec). $\mathrm{Z}$ gramatycznego punktu widzenia funkcjonująca do dziś nazwa miejscowa powstała w wyniku uniwerbizacji dwuwyrazowej formy wyjściowej Nowe Sioło za pomocą sufiksu -ec, użytego w funkcji strukturalnej, formującego gramatycznie nazwę w liczbie pojedynczej. Konstrukcyjnie w liczbie mnogiej odpowiada jej np. nazwa miejscowa Siedlce utworzona od staropolskiego określenia siodło, tj. 'wieś, osada' za pomocą sufiksu -ce.

Chociaż nie zachowały się bezpośrednie ślady onomastyczne, można $\mathrm{z}$ dużym prawdopodobieństwem zakładać, że stare sioło znajdowało się w niewielkiej odległości od nowego. Podstawę takiego przypuszczenia stanowią analogie w postaci nie tylko dwóch przytoczonych powyżej przykładów Siedlec i Białegostoku, ale również powszechnie występujących na terenie całego kraju nazw Stara Wieś. Najczęściej stanowią one odrębny toponim, notowany bezpośrednio $\mathrm{w}$ granicach lub $\mathrm{w}$ bliskim sąsiedztwie wielu miejscowości, współtworząc z „nowymi” ich częściami zwartą strefę zabudowy, stanowiąc odrębną wieś lub też sygnalizując lokalizację nieistniejących już siedlisk, będących inicjalnymi punktami rozwoju funkcjonujących osiedli, nierzadko stanowiąc jedno z ważnych miejsc symbolicznie różnicujących przestrzeń społeczną, a tym samym mających wpływ na kreowanie zbiorowej pamięci i tożsamości lokalnej wspólnoty (por. Assmann 2009 - tam literatura). Geneza tych nazw jest też przykładem międzypokoleniowej transmisji kulturowej. Jako grupa połączona znaczeniowo $\mathrm{z}$ tradycją zasiedlenia, mają więc one formę lingwistycznego znaku, który jako onomastyczny ślad przekształceń dokonujących się na płaszczyźnie osadniczej, zachowany został we współczesnej przestrzeni kulturowej (por. Wysoczański 2002 - tam literatura).

W omawianym przypadku taki „znak” istnieje w lokalnej świadomości wyłącznie w postaci nazwy miejscowej, jednak niewątpliwie rozumienie jej semantycznej treści uległo dezintegracji. Rekonstrukcja położenia domniemanego starego sioła stała się możliwa dzięki analizie dokumentacji i materiałów archeologicznych, pochodzących z badań powierzchniowych przeprowadzonych na gruntach wsi Nowosielec w 1988 r. przez Sławomira Żółkowskiego i w 2018 r. przez Bożenę Bryńczak (por. przypis 1). 
Proces lokalnej, chronologiczno-przestrzennej transformacji osadniczej dokumentuje dziewięć stanowisk archeologicznych (Nowosielec, gm. Łosice: st. 1/35, 2/36, 4/38, 5/39, 8/95 i 9/109; Dzięcioły, gm. Łosice, st. 4/43; Świniarów, gm. Łosice: st. 5/91 i 6/102 - ryc. 3$)^{5}$, na terenie których zebrano ceramikę datowaną na młodsze fazy wczesnego średniowiecza, późne średniowiecze, okres wczesnonowożytny i nowożytny. Materiał zabytkowy oraz rozmieszczenie stanowisk względem siebie pozwala postawić tezę o lokalnej kontynuacji zasiedlenia, którego początkowy etap nastąpił być może jeszcze w XI w. Propozycja ta warunkowana jest również założeniem, że mamy $\mathrm{w}$ tym przypadku do czynienia $\mathrm{z}$ demograficznym, gospodarczym i kulturowym rozwojem jednej i tej samej wspólnoty, na co może wskazywać ciągłość objawiająca się w nazwie miejscowości, w której zawarto „pamięćc" o starej osadzie.

Fazę wczesnośredniowieczną reprezentują ślady osadnictwa zarejestrowane jako st. 2/36 i 5/39 w Nowosielcu, $4 / 43$ w Dzięciołach i 5/91 w Świniarowie (ryc. 3: 2, 7, 8). Pierwsze $\mathrm{z}$ nich usytuowane jest na południowo-wschodnim stoku wybitnego cypla, uformowanego pomiędzy korytem Tocznej a jej niewielkim lewostronnym dopływem (ciek C1). Stanowisko o powierzchni szacowanej na około 15 ha, pozostające współcześnie w zasięgu pól uprawnych, jest w naturalny sposób delimitowane: od strony północno- i południowo-zachodniej przez pasmo wyniesień stanowiące kulminację nadrzecznego cypla, a od południowego i północnego wschodu przez podmokłe dno doliny Tocznej. Uwarunkowania te postrzegane były zapewne jako atrakcyjne osadniczo, gdyż najstarsze ślady takiej aktywności datowane są tam na okres starożytny (epoka brązu-wczesna epoka żelaza). Doceniono je także w średniowieczu, o czym świadczy obecność ceramiki, którą chronologicznie sytuować można być może już w XI w., a z pewnością w okresie XII-XIII w. i datować po XIV stulecie. Pozyskano ją z powierzchni (łącznie podczas prospekcji 1988 i 2018: 51 fragmentów naczyń). Na ślad osadniczy w postaci dwóch fragmentów ceramiki datowanych na XII-XIII w. natrafiono także na północnym stoku sąsiedniego cypla wysoczyznowego (ryc. 3: 4), ukształtowanego w widłach dwóch niewielkich strumieni (ryc. 3: cieki C1 i C2).

Zasiedlenie w późnym średniowieczu i we wczesnej nowożytności dokumentują materiały pozyska-

5 Dokumentacja KEZA w archiwum Narodowego Instytutu Dziedzictwa w Warszawie. ne na st. 2/36 oraz $8 / 95$ (ryc. 3: 2, 5a). W pierwszym przypadku jest to zapewne ślad kontynuacji osadnictwa mającego swój początek we wczesnym średniowieczu. Wśród materiałów zebranych z powierzchni wyodrębniono 22 fragmenty naczyń, które wydatowane zostały na okres od XV po XVII w. W drugim - obserwacje archeologiczne potwierdzają dane ze źródeł historycznych oraz kartograficznych, gdyż zarejestrowany punkt zasiedlenia to historyczna wieś Nowosielec funkcjonująca w okresie od XV do XIX w. i stanowiąca najstarszą fazę rozwoju współczesnej miejscowości o tej nazwie. Jej usytuowanie jest analogiczne do odnotowanego w przypadku osady starszej (por. ryc. 3: 2 i 5a). Nowe sioło powstało w odległości ok. $800 \mathrm{~m}$ na północny zachód od starego, na południowo-wschodnim stoku wybitnego cypla, uformowanego pomiędzy dwoma bezimiennymi dopływami Tocznej (ryc. 3: cieki C2 i C3). Różnica czytelna jest natomiast $\mathrm{w}$ odniesieniu do wysokości bezwzględnych: starsza osada rozwijała się w dolnej partii stoku, tuż nad poziomem terasy zalewowej doliny rzecznej, młodszą założono wyżej, w górnej części stoku i na skraju wysoczyzny, której wyniesienia zachowały się lokalnie w postaci nieregularnego pasma.

Analiza ceramiki ze starszej osady wykazała, że z dużym prawdopodobieństwem schyłek jej użytkowania datować można na XVI-XVII w. Na regionalnym gruncie historycznym cezurę tę hipotetycznie przyporządkować można do 2. połowy XVII w., kiedy lokalny rozwój osadnictwa poważnie zachwiany został w wyniku zniszczeń dokonanych przez wojska szwedzkie, siedmiogrodzkie i moskiewskie, pandemię dżumy oraz klęski nieurodzajów (Dobrowolski 2014, 163-169). Opisywany punkt osadniczy nie istniał już na początku XIX w., kiedy mapę tych terenów sporządzał Antoni M. von Heldensfeld (1804). Oznacza to jednak, że obydwa sioła: „stare” i ,nowe” (ryc. 3: 2, 5a) mogły wcześniej funkcjonować równolegle przez około 150 lat, po czym osiedle usytuowane bezpośrednio nad Toczną zostało opuszczone. Zasięg ekumeny wytworzonej przez obydwie osady we wczesnej nowożytności dokumentują dodatkowo datowane na ten sam okres ślady osadnictwa w postaci pojedynczych fragmentów ceramiki, odnotowane jako st. 1/35, 4/38 i 9/109 w Nowosielcu (ryc. 3: 1, 3, 6) oraz osady na st. 4/43 w Dzięciołach i 5/91 w Świniarowie. Ceramika pozyskana z powierzchni ostatnich dwóch wskazuje, że etap wczesnonowożytnego zasiedlenia, podobnie jak w przypadku starszej osady w Nowosielcu (ryc. 3: 2), poprzedzała tam średniowieczna faza osadnicza, datowana co najmniej od XII w. (ryc. 3: 7, 8). 


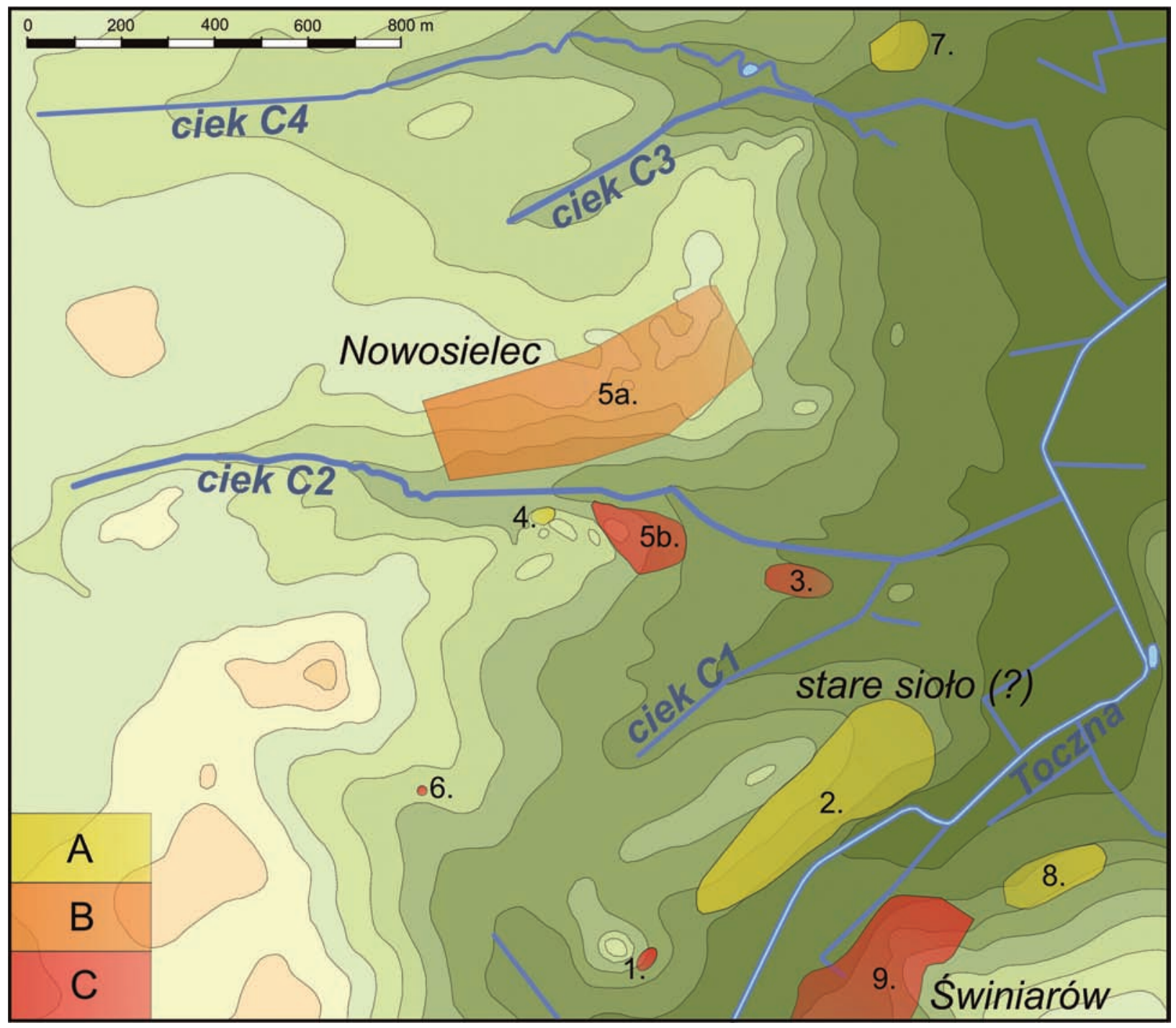

Ryc. 3. Średniowieczne i wczesnonowożytne osadnictwo okolic Nowosielca według wyników badań AZP i kwerend kartograficzno-historycznych (oprac. K. Skrzyńska na podstawie dokumentacji z badań 2018 r. wykonanej przez B. Bryńczak): 1. Nowosielec, st. 1/35 (ślad osadnictwa z XVI-XVII w.); 2. Nowosielec, st. 2/36 (osada z XI-XIV w. i z XV-XVII w.); 3. Nowosielec, st. 4/38 (ślad osadnictwa z okresu wczesnonowożytnego); 4. Nowosielec, st. 5/39 (ślad osadnictwa z XII-XIII w. i późnego średniowiecza oraz osada z XVII-XVIII w.); 5a i 5b. Nowosielec, st. 8/95 (wieś historyczna z XV-XIX w.); 6. Nowosielec, st. 9/109 (ślad osadnictwa z XVI-XVII w.); 7. Dzięcioły, st. 4/43 (osada z XI(?), XII-XIII w. i z XVI-XVIII w.); 8. Świniarów, st. 5/91 (ślady osadnictwa wczesnośredniowiecznego po XIII w. i z okresu wczesnonowożytnego); 9. Świniarów, st. 6/102 (wieś historyczna XVI-XIX w.); A - stanowiska $\mathrm{z}$ fazami zasiedlenia datowanymi od wczesnego średniowiecza po wczesną nowożytność; $\mathrm{B}$ - wieś historyczna

Nowosielec datowana od późnego średniowiecza po współczesność; C - punkty osadnicze powstałe we wczesnej nowożytności

Fig. 3. The medieval and early modern settlement near the village of Nowosielec according to the results of the AZP programme (Archaeological Picture of Poland) and cartographic-historical queries (prepared by K. Skrzyńska on the basis of the field research documentation of 2018, prepared by B. Bryńczak): 1. Nowosielec, site 1/35 (settlement trace from the 16th-17th centuries); 2 . Nowosielec, site $2 / 36$ (open settlements from the 11th-14th centuries and 15th-17th centuries); 3 . Nowosielec, site 4/38 (a trace of early modern settlement); 4. Nowosielec, site 5/39 (settlement traces from the 12th-13th centuries and from the late medieval period, open settlement from the 17th-18th centuries); $5 \mathrm{a}$ and 5b. Nowosielec, site $8 / 95$ (historical village from the 15 th-19th centuries); 6 . Nowosielec, site 9/109 (settlement trace from the 16th-17th centuries); 7. Dziecioły, site 4/43 (open settlements from the 11th (?) - the 12th-13th centuries and from the 16th-18th centuries); 8. Świniarów, site 5/91 (early medieval settlement traces dated down to the 13th century and settlement traces from the early modern period); 9. Świniarów, site 6/102 (historical village from the 16th-19th centuries); A - sites dated from the early middle ages to the early modern period; B - Nowosielec historical village dated from the Late Middle Ages till the present day; $\mathrm{C}$ - settlement points from the early modern period 
Najmłodszymi elementami tej struktury są wsie powstałe we wczesnej nowożytności, tj. południowa „zarzeczna” część Nowosielca (ryc. 3: 5b) oraz usytuowana po przeciwnej stronie Tocznej wieś Świniarów (ryc. 3: 9). Rozbudowa pierwszej z nich nastąpiła najpewniej w XVII w., a więc przypuszczalnie już po upadku starszej osady nad Toczną. Być może ten rozkwit przestrzenny wiązać należy właśnie z tym faktem. Dodatkowy sektor zabudowy wiejskiej istniał w XVII-XVIII w., poza ścisłymi granicami wsi historycznej, na południowym brzegu cieku C2 (część „zarzeczna”: st. 5/39 - ryc. 3: 5b). Osadnictwo to miało jednak charakter epizodyczny, gdyż zabudowania funkcjonujące tam na przełomie XVIII i XIX w. (por. ryc. 1) nie istniały już na początku XX w. (Mapa 1914a).

Dotychczasowe dane wskazują, że wczesnonowożytną metrykę ma także wspomniana wyżej wieś Świniarów (ryc. 3: 9). Pomimo interesującej nazwy, stanowiącej na terenie współczesnych ziem polskich formę izolowaną (jedyną), zawierającą być może treść semantyczną związaną z jej pierwotnie służebną funkcją, nie udało się jak dotąd archeologicznie potwierdzić średniowiecznej fazy jej funkcjonowania. Najstarsze wzmianki o Świniarowie w źródłach pisanych pochodzą natomiast z 2. połowy XVI w. (Gałecki 2019, 61-62).

Powstanie sioła, oznaczonego w ewidencji Archeologicznego Zdjęcia Polski numerem 2/36 (ryc. 3: 2), stanowiącego inicjalny punkt rozwoju niewielkiej ekumeny nad górną Toczną, z dużym prawdopodobieństwem łączyć można $\mathrm{z}$ formowaniem się zaplecza osadniczego wczesnośredniowiecznego grodu w pobliskich Dzięciołach. Fortyfikacja ta hipotetycznie identyfikowana jest jako pozostałość przedlokacyjnych Łosic (Mikulski 1969; Aleksandrowicz 1969; Skrzyńska 2019b; 2019c). Z uwagi na imponujące rozmiary oraz obecność kilkuliniowego systemu umocnień obronnych można przypuszczać, że obiekt ten pełnił nadrzędną funkcję w regionalnej sieci grodowej, swą formą wyróżniając się także na całym obszarze pogranicza polsko-ruskiego w międzyrzeczu Wisły i Bugu (Skrzyńska 2019a). Powstanie i funkcjonowanie tego założenia, datowane wstępnie na XII w. (Górska et al. 1976, 44-45), związane było prawdopodobnie z potrzebą administracyjnego i osadniczego zorganizowania obszaru dorzecza Tocznej, który około połowy XI w. znalazł się formalnie w zasięgu księstwa włodzimierskiego (por. Skrzyńska 2014, 221-229), stając się częścią polsko-ruskiego pogranicza międzypaństwowego oraz konstytuującej się tam domeny terytorialnej, której ośrodkiem centralnym był wówczas gród Drohiczyn (Skrzyńska-Jankowska 2004; Andrzejewski, Sikora 2009, 153-155; Jusupović 2010).

Analizy osadnicze wykazały, że proces ten miał $\mathrm{w}$ regionie przebieg co najmniej dwutorowy: $\mathrm{z}$ jednej strony mógł on polegać na adaptacji wykrystalizowanych struktur osadniczych, funkcjonujących od starszych faz wczesnego średniowiecza, a z drugiej na aktywnej kolonizacji obszarów, które w dobie przedpaństwowej pozostawały niezagospodarowane (Skrzyńska, Bryńczak 2019). Zaobserwowano, że najstarsze strefy zasiedlenia, powstające na terenie dorzecza górnej Tocznej w okresie od VII do X w., rozwijały się $\mathrm{w}$ dolinach niewielkich cieków, stanowiących dopływy głównej rzeki (ryc. 4). Widoczne są również lokalne preferencje wskazujące, że we wspomnianej fazie za najbardziej atrakcyjne w perspektywie osadniczej uznawano źródłowe i górne odcinki dolin rzecznych. W młodszym etapie (wczesnopaństwowym) datowanym ramowo na XI-XII w. pojawiło się osadnictwo bezpośrednio związane $\mathrm{z}$ doliną Tocznej, przy czym usytuowanie nowych osad wzdłuż rzeki nosi znamiona planowego rozmieszczenia. Aktywność ta, związana z zasiedlaniem dotąd niezagospodarowanych obszarów, mogła być zorganizowaną akcją, z jednej strony ukierunkowaną na wytworzenie odpowiedniego zaplecza osadniczego dla pobliskiej fortyfikacji, a z drugiej łączącą się być może z powstaniem lokalnego odcinka traktu łączącego Drohiczyn z grodami stołecznymi: Wołyniem i Włodzimierzem Wołyńskim, a następnie z Chełmem oraz z ośrodkami wschodniej Małopolski (Dunin-Wąsowicz 2011 [1982], 275-276, 278, ryc. 4; Skrzyńska-Jankowska 2014, 578-606). Z dużym prawdopodobieństwem można również zakładać, że w rejonie tym znajdował się węzeł drożny, stanowiący początek osobnego traktu prowadzącego do przepraw bużańskich $\mathrm{w}$ rejonie Brześcia i Mielnika. Właśnie z tym etapem rozwoju kulturowego dorzecza Tocznej można łączyć inicjalną fazę funkcjonowania osady na st. 2/36 w Nowosielcu oraz związanego z nią rozwoju lokalnej ekumeny, sukcesywnie powiększanej w ciągu następnych kilku stuleci. Nowe punkty osadnicze w: Dzięciołach (kompleks w postaci grodu i osad przygrodowych), Nowosielcu (domniemane Stare Sioło) oraz w Łosicach usytuowane były na obydwu brzegach Tocznej 


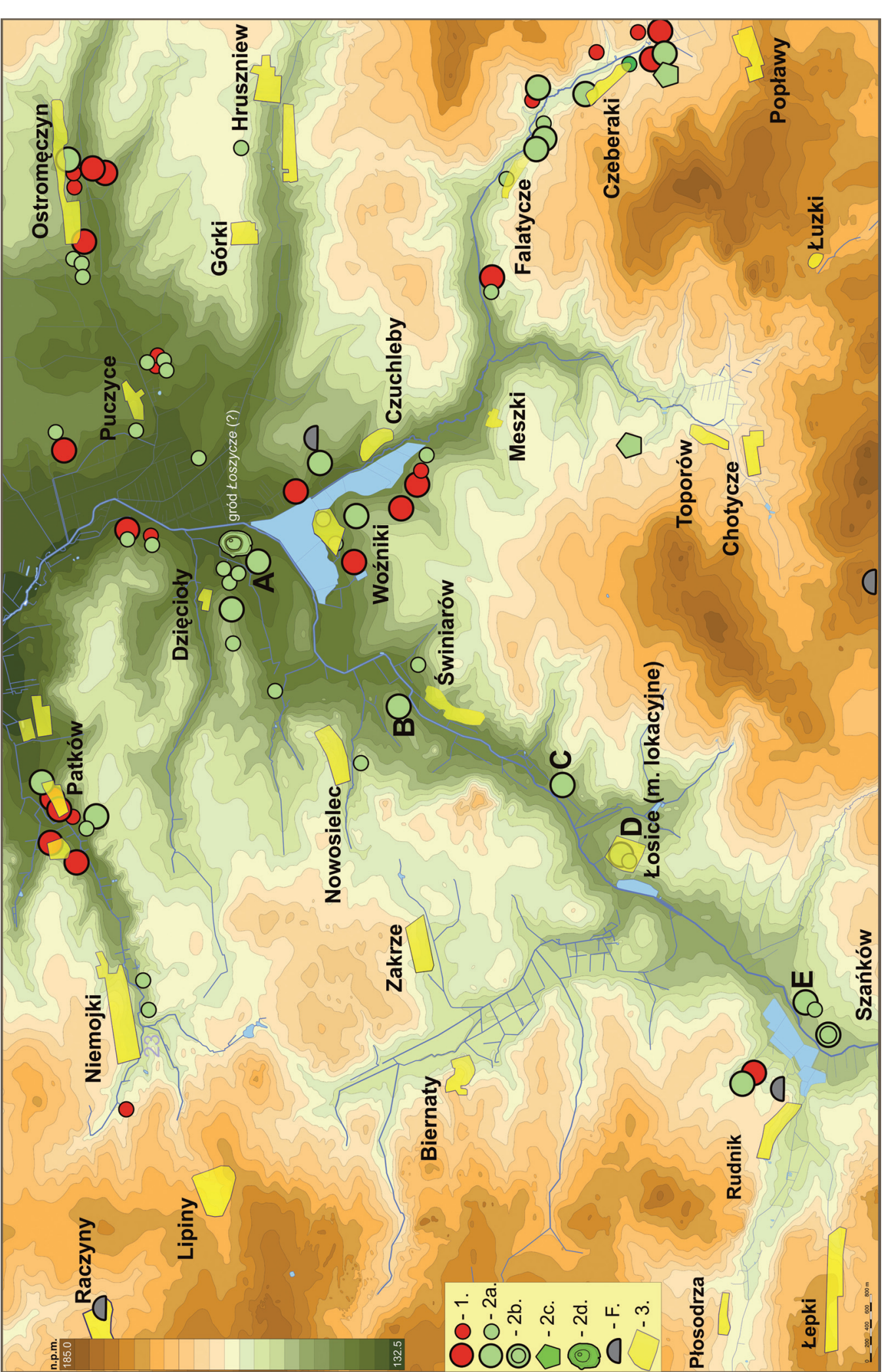

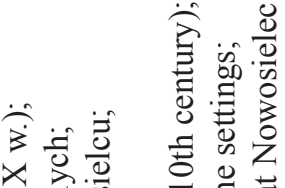

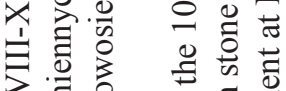

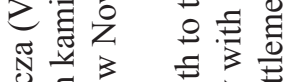
过范

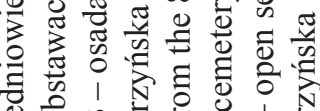

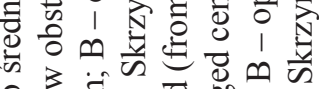

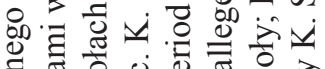

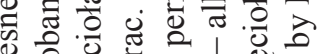

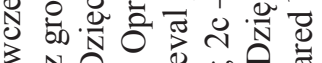

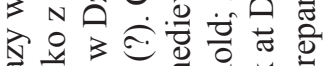

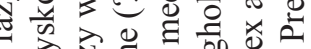

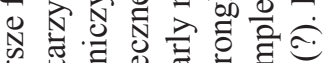

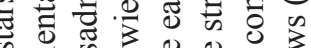
क है

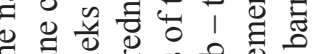

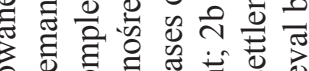

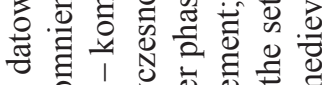

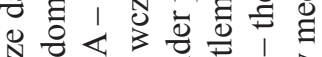

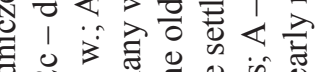

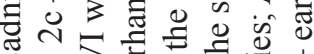

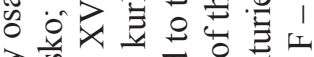

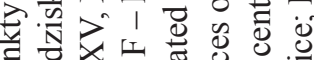

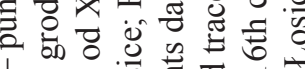

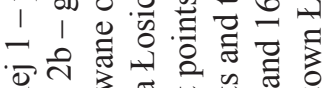

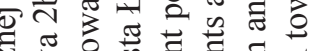

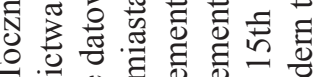

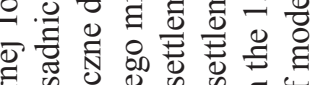

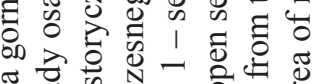

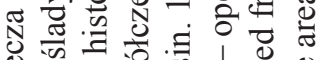

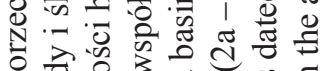

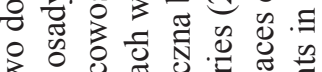

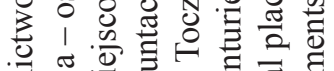

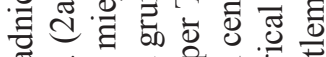

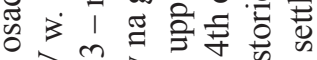

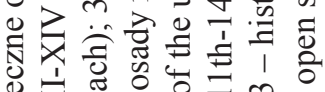
文 $\frac{\pi}{0} 0$ 员

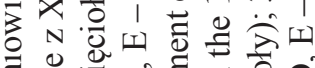

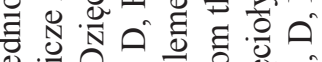

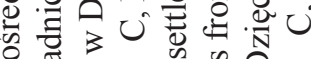

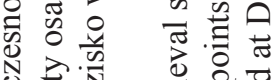

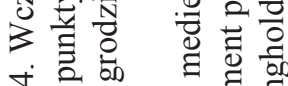
小

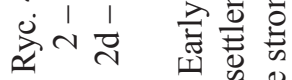

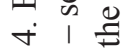
我 $\frac{1}{2}$ 
w układzie wyraźnie liniowym i w mniej więcej równej odległości względem siebie, wynoszącej od 1 do 2 km (ryc. 4: A-E).

\section{ANALOGIE REGIONALNE}

Opisany przykład nowosieleckiego mikroregionu osadniczego jest jednym z kilku, jakie odnotowano w dorzeczu górnej Tocznej w kontekście analizy ciągłości zasiedlenia oraz przeobrażeń, które dokonały się w lokalizacji i kształcie poszczególnych punktów osadniczych. W mikroregionalnym obrazie organizacji przestrzeni, wytworzonym w ramach kilku tamtejszych ekumen, czytelne są zasadnicze zmiany socjotopografii zasiedlenia dokonujące się według analogicznego schematu (por. ryc. 4). Jednak tylko w przypadku Nowosielca zachował się onomastyczny ślad tego procesu. W odniesieniu do innych skupisk osadniczych, których rozwój zainicjowany został we wczesnym średniowieczu, wyrazem potwierdzonej archeologicznie ciągłości zasiedlenia są toponimy przynależące do najstarszych warstw nazewniczych (Gałecki 2019). Wywodzą się one od staroruskich apelatywów i nazw osobowych, przynależąc m.in. do typów: nazw patronimicznych (np. Puczyce, Chwalatycze [wsp. Falatycze], Chotycze, Patkowicze [wsp. Patków], Łoszycze [wsp. Łosice]), służebnych (np. Woźniki, Tokary, Świniarów [?]), rodowych (np. Czuchleby, Czeberaki) i innych (np. Ostromęczyn, \{Nowo\}Sielec). Badania archeologiczne wykazały, że najstarsze punkty osadnicze istniały tam w VIII-X w., a w przypadku Puczyc i Czeberak dopuszcza się moŻliwość ich VII-wiecznej metryki (Skrzyńska, Bryńczak 2019, 117). Wsie późnośredniowieczne o wymienionych wyżej nazwach sytuowane były w bliskim lub bezpośrednim sąsiedztwie wczesnośredniowiecznych osad (Puczyce, Świniarów, Nowosielec - ok. 800 m; Ostromęczyn - na krawędzi wysoczyzny, równolegle do wczesnośredniowiecznych osad usytuowanych na stoku doliny; Czuchleby - ok. 750 m, na przeciwległym brzegu rzeki; Patków - ok. $700 \mathrm{~m}$, na tym samym brzegu rzeki; Falatycze - obok i na terenie osad datowanych na XII-XIII w., po obydwu brzegach rzeki; Czeberaki, Woźniki (dwór i folwark) - pomiędzy wczesnośredniowiecznymi osadami na obydwu brzegach rzeki). Dwie wyjątkowe sytuacje zaobserwowano w odniesieniu do miejscowości Chotycze ${ }^{6}$

6 W bezpośrednim sąsiedztwie wsi Chotycze nie odnaleziono jak dotąd śladów osad wczesnośredniowiecz- i Łosice ${ }^{7}$. Ich nazwy reprezentują najstarszą warstwę onomastyczną, rozpoznaną na terenie regionu, tj. patronimiki.

Cechy chronologiczno-przestrzennych przemian w strukturze zasiedlenia omówionych na przykładzie Nowosielca są szczególnie dobrze czytelne w odniesieniu do dwóch mikroregionów usytuowanych w tym samym kontekście geograficzno-kulturowym, tj. w przypadku Czuchlebów-Woźnik i Falatycz-Czeberak, gm. Łosice (ryc. 5: a, b).

Mikroregion osadniczy związany $\mathrm{z}$ pierwszą z wymienionych wsi kształtował się na stokach doliny dolnego biegu rzeki Kałuży, stanowiącej jeden z większych dopływów Tocznej. Inicjalne punkty osadnicze, których funkcjonowanie wydatowano na IX-XI w. współtworzyły tam trzy osady usytuowane w strefie niższych partii stoków doliny rzecznej, tuż nad poziomem zalewowym (ryc. 5a: 3/17, 6/21, 9/34). Wydaje się, że dla rozwoju osadniczego mikroregionu najistotniejsze znaczenie miały dwie z nich (3/17 i 9/34), usytuowane po obu stronach ujścia Kałuży i eksponowane w kierunku północno-zachodnim, tj. ku dolinie Tocznej. Ich naprzeciwległa lokalizacja i „parzysty” układ powielany przez późniejsze punkty

nych. Sytuacja ta wynikać może ze stanu badań, gdyż na obecność takich punktów osadniczych wskazuje zarejestrowane tam cmentarzysko kurhanowe. Onomastyczny ślad tego stanowiska, w postaci nazwy miejscowej „Kurhany", znany był archeologom od dawna. Jeden rozmyty nasyp, wraz z przypuszczalnymi reliktami kolejnych trzech, rozmieszczonych liniowo na osi NW-SE, zidentyfikowano podczas badań powierzchniowych 2013 i 2018 r. (KEZA: Chotycze, gm. Łosice, st. 1/2). Stanowisko usytuowane jest w odległości $1,5 \mathrm{~km}$ na południowy zachód od wczesnonowożytnej wsi. Analizując ustalenia Joanny Kalagi (2006, 96 n.), przypuszczać można, że we wczesnym średniowieczu cmentarz ten mógł wyznaczać skraj ekumeny, której osią zasiedlenia był z pewnością obszar źródłowy niewielkiego cieku - pośredniego dopływu Tocznej.

$7 \mathrm{Na}$ terenie współczesnego miasta, w sąsiedztwie średniowiecznej lokacji natrafiono na ślady osadnictwa z XII w. i osadę datowaną na XIII w. (Łosice, gm. loco, st. 1/3). Była ona usytuowana na stoku doliny rzecznej, w miejscu rekonstruowanej przeprawy przez Toczną. Źródła archeologiczne wskazują jednak, że miasto mogło powstać w efekcie translokacji lokalnego ośrodka władzy i administracji terytorialnej, która nastąpić mogła w XIII lub nawet w XIV w. z pobliskiego grodu, którego pozostałością jest grodzisko we wsi Dzięcioły, gm. Łosice (st. 1/2). Przypuszcza się, że wraz z prerogatywami administracji i władzy terytorialnej oraz $\mathrm{z}$ domniemaną cerkwią, translokowano również nazwę ugruntowaną w lokalnej tradycji (Skrzyńska 2019a; 2019c). 


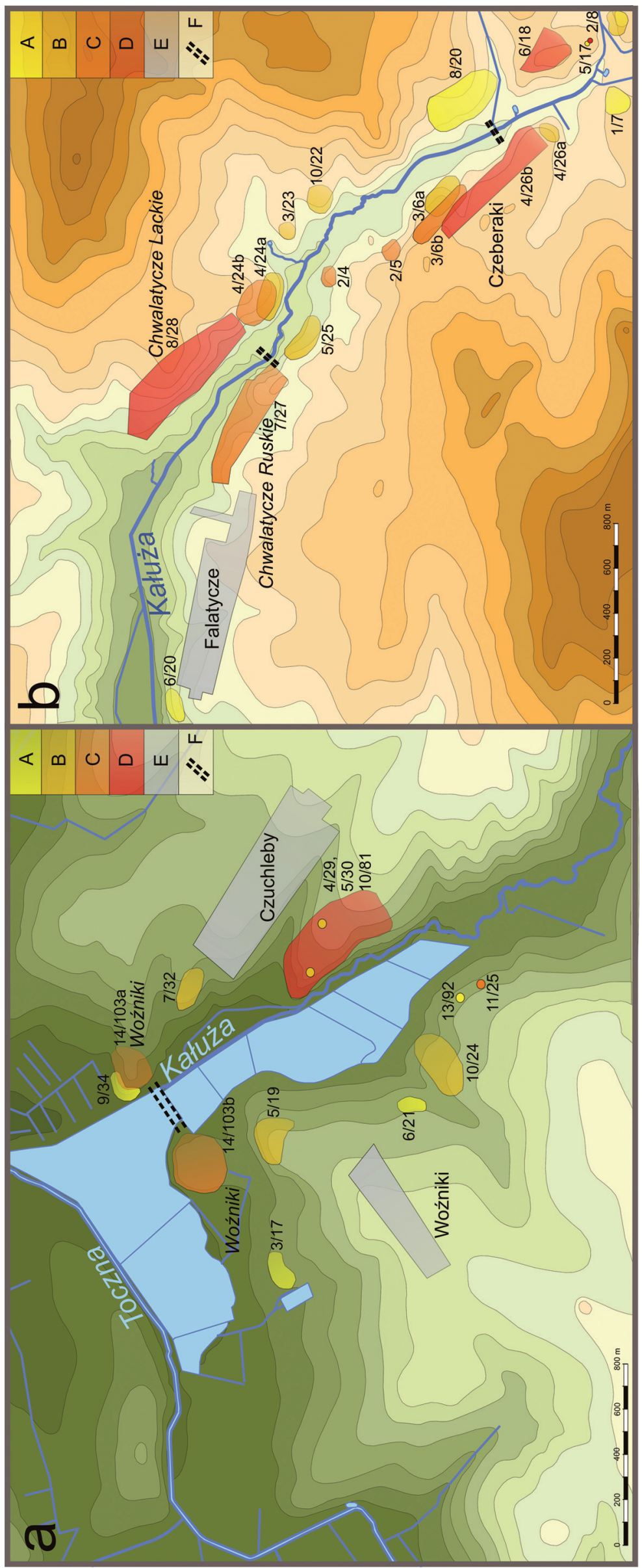

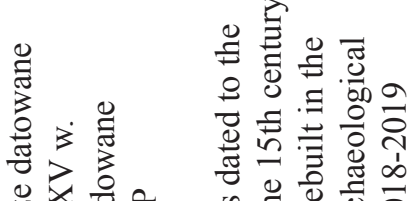

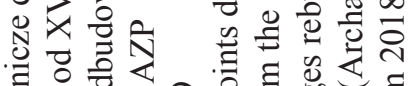

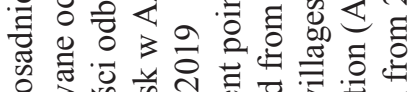
굴

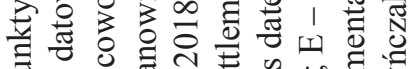

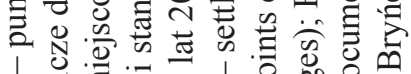
$<:$

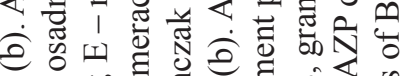

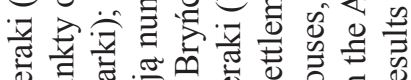

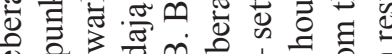

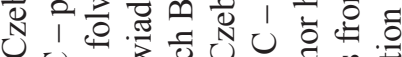
U 讨 专. 臣.

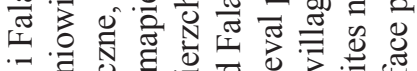

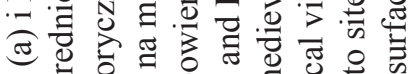

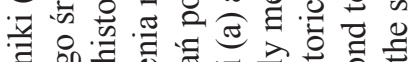

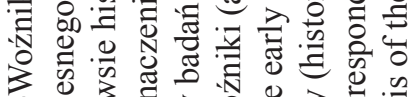

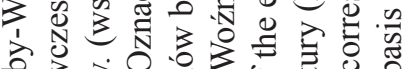

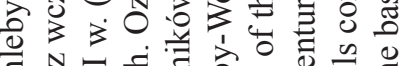

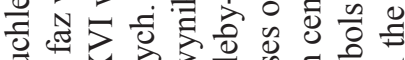
궝

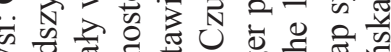

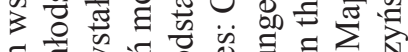

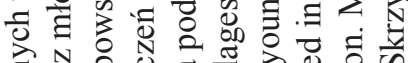
N 员

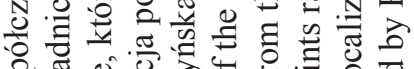

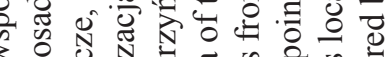

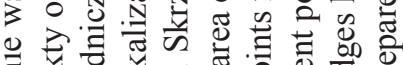

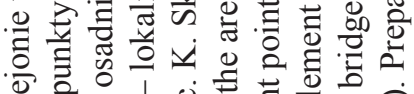

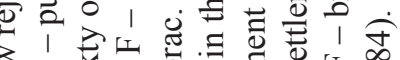

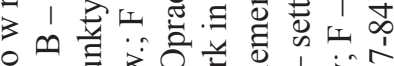

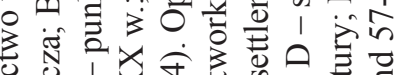

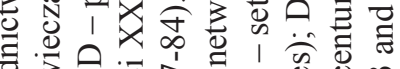

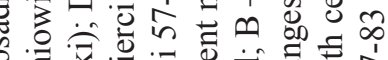

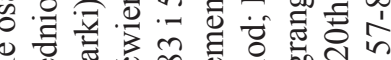

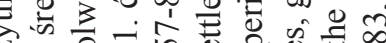

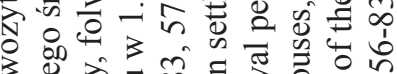

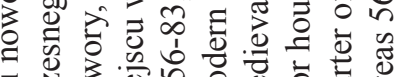

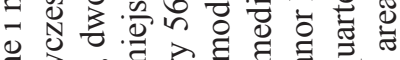

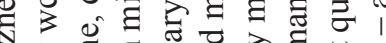

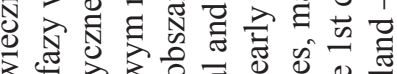

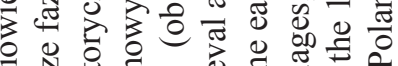

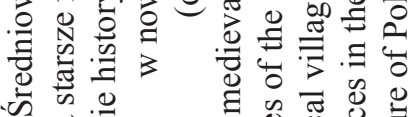

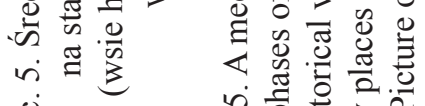

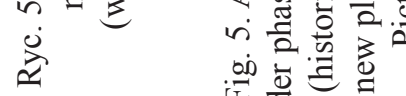
完它远焉 
osadnicze (5/19 i 7/32 - młodsze fazy wczesnego średniowiecza; 14/103a i 14/103b - późne średniowiecze i okres wczesnonowożytny) wskazują, że mogło to być miejsce lokalnej przeprawy przez Kałużę, usytuowanej na trakcie wiodącym z Łosic w kierunku Puczyc, Ostromęczyna i Chłopkowa oraz dalej w kierunku przepraw przez Bug. Przebieg tego szlaku oraz oznaczenie mostu w Woźnikach poświadczone jest filologicznie w XVI w. jako „droga wielka woźnicka" (Inwentarz, 198v) oraz kartograficznie dla końca XVII w. (A. M. Heldensfeld 1804). Co najmniej od 1. ćwierci XV w. w lokalizacji tej funkcjonował dwór woźnicki wraz z usytuowanym po przeciwnej stronie rzeki folwarkiem (ryc. 5a: 14/103a i 14/103b). Już wówczas stanowił on centralny punkt rozległych dóbr hospodarskich (Dobrowolski 2019, 75-78). Na jego zapleczu, co najmniej od XVI w. do początku XX w. funkcjonowała wieś o ruskiej nazwie Czuchleby od bł. rus. nazwy osobowej Czuchleb (SG 1880, 887; Gałecki 2019, 33 - por. ryc. 5a: 10/81). Po pożarze, jaki miał miejsce w 1911 r., odbudowano ją w nowym miejscu - w odległości ok. $300 \mathrm{~m}$ na północny wschód, po przeciwnej stronie doliny niewielkiego cieku. W tej lokalizacji miejscowość ta funkcjonuje obecnie.

Współczesna wieś Woźniki jest najmłodszym elementem omawianego kompleksu osadniczego, który pojawił się dopiero po II wojnie światowej. Usytuowano ją na terenie skraju wysoczyzny, całkowicie poza granicami strefy historycznego zasiedlenia. Osadnictwo nie rozwijało się tam ani we wczesnej nowożytności, ani później, co poświadczają źródła kartograficzne (A. M. von Heldensfeld 1804; Mapa 1914b). Wstępna kwerenda wskazuje, że historyczna wieś Woźniki, której funkcjonowanie datować można od wczesnego średniowiecza po nowożytność, znajdowała się na prawym brzegu Tocznej, nad niewielkim strumieniem, w odległości ok. 200 m od północno-wschodniego skraju wsi Świniarów (por. ryc. 3: 8) ${ }^{8}$. Nazwa Woźniki ma rodowód średniowieczny i związana jest ze służebną funkcją zamieszkującej ją ludności. Wchodzi ona w skład zespołu 15 nazw wsi służebnych odnotowanych na terenie międzyrzecza Bugu, Liwca i Krzny, wyraźnie odróżniającego się w tym aspekcie od regionów sąsiednich, gdzie typ ten nie występuje (Gałecki 2019, 58-59, ryc. 14).

8 Problem lokalizacji historycznej wsi Woźniki zauważyliśmy dopiero na etapie konstruowania bieżącego tekstu. Z uwagi na złożoność potencjalnej rekonstrukcji archeologiczno-historycznej, powinien on stać się tematem odrębnej analizy.
W związku z obecnością analogicznie nazwanych osad na terenie średniowiecznej Polski, pochodzenie substratu etnicznego tworzącego założycielską, lokalną wspólnotę wiejską Woźnik należy hipotetycznie łączyć z osadnictwem zachodniosłowiańskim. Jego obecność być może thumaczyć można zaistnieniem w dziejach pobliskiego grodu epizodu historycznego łączącego się z czasową zmianą przynależności terytorialnej (por. Gałecki 2019, 62-64; Skrzyńska 2019a, 175-177).

Początkowa faza rozwoju drugiego mikroregionu osadniczego, określonego roboczo jako Czeberaki-Falatycze, datowana jest na VIII-IX w., z etapem inicjalnym sytuowanym może nawet w VII w. (Skrzyńska, Bryńczak 2019, 117, 119). Najstarsze osady założono przede wszystkim w źródłowym odcinku doliny rzeki Kałuży, u zbiegu kilku współtworzących go strumieni (ryc. 5b: 1/7, 2/8, 8/20). Następnie, w młodszych fazach wczesnego średniowiecza, zasiedlenie postępowało w kierunku północno-zachodnim, a nowe punkty osadnicze powstały w niewielkiej, kilkusetmetrowej odległości od starszych, w dolnych partiach stoków doliny rzecznej, po obydwu jej stronach (ryc. 5b: 4/26a, 3/6a, 10/22, 2/23, 5/25, 4/24a). Centralnym punktem mikroregionu stał się wówczas kompleks czterech osad, usytuowanych pomiędzy współczesnymi miejscowościami Falatycze i Czeberaki (ryc. 5b: $4 / 24 a, 5 / 25,3 / 23,10 / 22$ ). Ich charakterystyczne przeciwstawne położenie po obydwu stronach cieku wskazuje, że mogły rozwijać się w miejscu zapewniającym dogodne przejście przez rzekę. Jak się zdaje, jego lokalizację odzwierciedla przebieg współczesnej drogi, który nie uległ zasadniczym zmianom co najmniej od końca XVIII w. (A. M. von Heldensfeld 1804; por. ryc. $5 b)$. W późnym średniowieczu i na początku okresu wczesnonowożytnego lokalny obraz zasiedlenia uległ tylko nieznacznym korektom. Nowe osady pozostały w bezpośredniej relacji przestrzennej ze starszymi, gdyż założono je bądź w sąsiedztwie wczesnośredniowiecznych, bądź kontynuowano zasiedlenie w tych samych miejscach, przy przeniesieniu aktywności osadniczej w rejon górnych partii stoków i krawędzi doliny rzecznej (ryc. 5b: 3/6b, 2/5, 2/4, 4/24b, 7/27). Według źródeł pisanych i kartograficznych powstałe wówczas osady identyfikować można $\mathrm{z}$ historycznymi wsiami Czeberaki i Chwalatycze (SG 1880, 778 ryc. 5b: 3/6b, 7/27). Lokalizacja pierwszej z wymienionych uległa niewielkiej zmianie w fazie wczesnonowożytnej, gdyż w XVI-XVII w. zwarta zabudowa wiejska funkcjonowała $\mathrm{w}$ bezpośrednim kontekście starszej, ale nowa wieś usytuowana została nieco wy- 
żej od poprzedniej - na krawędzi wysoczyzny (por. ryc. 5b: 4/26b). Inaczej przebiegł rozwój przestrzenny wsi Chwalatycze, gdyż w XVI-XVII w. naprzeciwko osady średniowiecznej (ryc. 5b: 7/27) istniała wieś założona prawdopodobnie przez polskich osadników (ryc. 5b: 8/28). Rozbudowa ta mogła nastąpić jeszcze w XV w. (por. Jaszczołt 2006), a być może dopiero po inkorporacji Podlasia do Korony Polskiej w 2. połowie XVI w. (Maroszek 2013, 126-139). Zmiany zaszły również w warstwie nazewniczej, gdyż nową część miejscowości wyróżniano wówczas określeniem „Lackie”, w opozycji do starszej „Ruskiej” wsi położonej na przeciwległym brzegu rzeki. Obydwa etnonimy wskazują na różnice etniczno-językowe pomiędzy zamieszkującymi je społecznościami (Gałecki 2010, 165-166). Po południowo-wschodniej stronie Chwalatycz Lackich, w miejscu starej osady średniowiecznej (ryc. 5b: 4/24), w XVII w. istniał dwór i folwark (A. M. von Heldensfeld 1804; SG 1880, 778). Taka sama reorganizacja przestrzeni osadniczej nastąpiła również w Czeberakach (A. M. von Heldensfeld 1804; SG 1880, 778), gdzie dwór i folwark założono w nieco większej odległości od wsi, na przeciwległym brzegu Kałuży (ryc. 5b: 6/18). Kompleks ten przestał istnieć prawdopodobnie w XIX w. Z uwagi na zniszczenia dokonane w wyniku toczących się walk powstańczych, prześladowań wyznaniowych i notowanych lokalnie niepokojów społecznych (Dobrowolski 2014, 196-237; 2018), okres ten należy traktować jako kolejną ważną cezurę w rozwoju kulturowym regionu. Na początku XX stulecia historyczną lokalizację zachowały tylko: dwór i folwark w Falatyczach oraz wieś Czeberaki. Pozostałe struktury wykrystalizowane $\mathrm{w}$ XV-XVI w. zostały zniszczone, a teren na którym wcześniej funkcjonowało osadnictwo pozostawał niezabudowany. Wieś Falatycze odbudowano bez uwzględnienia podziału na część „lacką” i „ruską" - w 1914 r. funkcjonowała ona już we współczesnej lokalizacji (Mapa 1914b; ryc. 5b).

Obydwie nazwy miejscowe w oryginalnym brzmieniu Czeberaki od ukr. nazwy osobowej Czeberiak i Chwalatycze od rus. nazwy osobowej Chwaliata są pochodzenia staroruskiego, ale przynależą do dwóch odmiennych typów. Pierwsza z nich należy do nazw rodowych (Gałecki 2019, 33). Natomiast druga reprezentuje najstarszą regionalną warstwę nazewniczą patronimików, których wiele odnotowano na terenie międzyrzecza Bugu, Liwca i Krzny (Gałecki 2019, $35,45-47)$.

\section{PODSUMOWANIE}

Załamanie się wczesnośredniowiecznych struktur osadniczych, w świetle wyników badań archeologicznych, dokonało się w dorzeczu Tocznej najpewniej dopiero w XIV stuleciu (Skrzyńska, Bryńczak 2019), po upadku dynastii Romanowiczów, w efekcie procesu przejmowania ziem księstwa halickowłodzimierskiego przez Polskę i Litwę. Regres ten był, jak się zdaje, determinowany trwającą około 100 lat recesją polityczno-gospodarczą (por. Janeczek 2011, 239-246), której towarzyszyły obustronne działania militarne (Bieniak 2000; Wojtowycz 2011; Maroszek 2013, 23-45). Brakuje natomiast archeologicznego potwierdzenia, że jakakolwiek destabilizacja osadnictwa miała tam miejsce w XIII w., kiedy obszar ten znalazł się w zasięgu najazdów tatarskich, litewskich i polskich 1. i 2. połowy XIII w. Równolegle do procesu dezintegracji starej sieci osadniczej w XIV-XV w. obserwowane jest powstawanie nowej, organizowanej jak się zdaje już na odmiennych zasadach, dyktowanych zmianą systemu administrowania oraz powstaniem nowych podziałów własności ziemskiej (por. Dobrowolski 2019, 74-109). Znaczący wpływ na zmianę krajobrazu kulturowego miała również intensywna kolonizacja (Wiśniewski 1964; Jaszczołt 2006; 2013, 74-86; Pytasz-Kołodziejczyk 2018), w wyniku której, szczególnie w zachodniej części regionu, uformowała się zwarta sieć wsi o charakterze drobnoszlacheckim. W odniesieniu do wyników badań powierzchniowych, stwierdzić należy, że lokowano je głównie na terenach dotąd niezasiedlonych (por. ryc. 4). W odniesieniu do „starych" mikroregionów osadniczych, powstałych w dorzeczu górnej Tocznej jeszcze we wczesnym średniowieczu, przeobrażenia te polegały w głównej mierze na zmianie lokalizacji osad, przenoszonych na tereny dotąd niezasiedlone, ale znajdujące się w granicach wykrystalizowanych ekumen. Osadnictwo było tam jednocześnie reorganizowane według nowych, zestandaryzowanych schematów, zaczerpniętych z reguł lokacyjnych. Obserwacje archeologiczne wykazały jednak, że nowe wsie zakładano w bezpośrednim lub bliskim sąsiedztwie starych osad. Na obecnym etapie badań trudno stwierdzić, czy opuszczenie tych ostatnich miało formę definiowalnego chronologicznie epizodu, czy też było procesem długotrwałym. Przykład prawdopodobnego, równoległego funkcjonowania „nowego" i „starego” sioła w Nowosielcu wskazuje, że 
przynajmniej część osad przetrwała, a proces ich opuszczania przebiegał stopniowo, być może w po- wiązaniu z sukcesywnym zmniejszaniem się ich potencjału demograficznego.

\section{BIBLIOGRAFIA}

\section{Źródła:}

Akty

1908 Akty izdawajemyje Wilenskoju Komissijeju dla razbora drewnich aktow. T. XXXIII. Akty otnosiaszczijesia $\mathrm{k}$ isstorii zapadnorusskoj cerkwi. Wilno, s. 407-536.

von Heldensfeld Antoni M.

1804 Die Karte von Westgallizien, skala 1:28 800, kol. XVII, sekcja 225: Łosice.

Baliński M., Lipiński T. (1846). Starożytna Polska pod względem historycznym, jeograficznym $i$ statystycznym opisana, t. III, wyd. I. Warszawa: S. Olgerbrand Księgarz przy ulicy Miodowej nr 496.

Baliński M., Lipiński T. (1886). Starożytna Polska pod względem historycznym, jeograficznym $i$ statystycznym opisana, t. III, wyd. II poprawione i uzupełnione przez F.K. Martynowskiego. Warszawa: S. Olgerbrand Synowie Krakowskie-Przedmieście nr 66.

Inwentarz

Inwentarz starostwa mielnickiego $i$ tosickiego. An. 1551. Archiwum Główne Akt Dawnych. Archiwum Skarbu Koronnego LVI, M 2, I. Mapa

1914aKałuszyn-Siedlce-Międzyrzecz.Austriackakopia rosyjskiejtrójwiorstówki1:126000,godłoXVIII1(http:// maps.mapywig.org/m/K.u.K._maps/series/126K _Russland_WW1/XVIII-1_KuK_126K_Kaluszyn-Siedlce-Miedzyrzecze.jpg - dostęp: 10.03.2020)

1914b Siemjaticzi-Brest-Litowsk. Austriacka kopia rosyjskiej trójwiorstówki 1:126000, godło XVIII2 (http:// maps.mapywig.org/m/K.u.K._maps/series/126K_ Russland_WW1/XVIII-2_Kuk_126K_SiemjaticziBrest-Litowsk.jpg - dostęp: 19.04.2020) MK

Metryka Koronna [Metryka Królestwa Polskiego], Archiwum AGAD: Inwentarz Metryki Koronnej. Księgi wpisów i dekretów polskiej kancelarii królewskiej z lat 1447-1795, oprac. I. Sułkowska-Kurasiowa, M. Woźniakowa http://www.agad.gov.pl/inwentarze/ Metr_Korx.xml, [dostęp: 25.04.2020].
MpChrzan

1859 Karta dawnej Polski z przylegtymi okolicami krajów sasiednich na 1: 300000 . Oprac. i wyd. W. Chrzanowski, Paryż (BU KUL, Zbiory Kartograficzne).

MpKwat

1839 Topograficzna karta Królestwa Polskiego [Warszawa].

MpPerPd

1795 Mappa szczególna województwa podlaskiego zrzadzona... przez K. de Perthees... Skala 1: 225000 (Warszawa, AGAD, Zbiory Kartograficzne, AK 98).

\section{NMPol}

1996-2017 Nazwy miejscowe Polski. Historia. Pochodzenie. Zmiany, (red.) K. Rymut, B. Czopek-Kopciuch, U. Bijak. T. I-XIV, Kraków.

Rymut K. (1999-2001). Nazwiska Polaków. Stownik historyczno-etymologiczny. T. I-II. Kraków: Wydawnictwo Instytutu Języka Polskiego PAN.

SG

1880-1902 Stownik geograficzny Królestwa Polskiego $i$ innych krajów stowiańskich. Wyd. pod red. F. Sulimierskiego, B. Chlebowskiego, W. Walewskiego. T. I-XV. Warszawa.

SHG

Slownik historyczno-geograficzny województwa podlaskiego $w$ średniowieczu (materiały rękopiśmienne J. Wiśniewskiego). Źródło cytowane za NMPol. Sk IV

1924 Skorowidz miejscowości Rzeczpospolitej Polskiej opracowany na podstawie wyników pierwszego powszechnego spisu ludności z dn. 30 IX 1921 r. T. IV. Województwo lubelskie. Warszawa. Źródło cytowane za NMPol.

SStp

1953-2002 Stownik staropolski, (red.) S. Urbańczyk. T. I-XI. Wrocław-Kraków-Warszawa. 2005 Opis źródeł Słownika staropololskiego, (red.) W. Twardzik, Kraków.

Tabella

1827 Tabella miast, wsi, osad Królestwa Polskiego, $z$ wyrażeniem ich potożenia $i$ ludności alfabetycznie utożona... T. I-II. Warszawa. 
UNłos

1971 Urzędowe nazwy miejscowości i obiektów fizjograficznych. 128. Powiat tosicki, województwo warszawskie [Warszawa].

ŹDz. XVII

1908-1910 Aleksander Jabłonowski. Polska XVI wieku pod względem geograficzno-statystycznym. T. VI: Podlasie (województwo). Cz. 1-3. Źródła dziejowe XVII/1-3, Warszawa.

\section{Literatura:}

Alexandrowicz S. (1969). Zarys dziejów Łosic w XIIIXVIII w. W: J. Kazimierski (red.), Łosice 1264-1966 (9-29). Warszawa: Polskie Wydawnictwo Naukowe.

Andrzejewska A. (2008). Góra zamkowa w Mielniku w świetle ostatnich badań terenowych. Podlaskie Zeszyty Archeologiczne, 4, 223-245.

Andrzejewski A., Sikora J. (2009). Drohiczyn średniowieczny i nowożytny w świetle badań z roku 2006. Podlaskie Zeszyty Archeologiczne, 5, 153-195.

Assmann A. (2009). Przestrzenie pamięci. Formy i przemiany pamięci kulturowej. W: M. Saryusz-Wolska (red.), Pamięć zbiorowa i kulturowa. Wspótczesna perspektywa niemiecka (101-142). Kraków: Universitas.

Bieniak J. (2000). Wygaśnięcie książąt halickowłodzimierskich. W: H. Manikowska, A. Bartoszewicz, W. Fałkowski (red.), Aetas media. Aetas moderna. Studia ofiarowane profesorowi Henrykowi Samsonowiczowi $w$ siedemdziesiata rocznice urodzin (387-392). Warszawa: Instytut Historyczny Uniwersytetu Warszawskiego.

Boryś W. (2005). Stownik etymologiczny języka polskiego. Kraków: Wydawnictwo Literackie.

Dobrowolski T. (2014). 750 lat Ziemi Łosickiej. Łosice i Ziemia Łosicka $w$ latach 1264-1939, t. I. Łosice: Urząd Miasta i Gminy w Łosicach.

Dobrowolski T. (2018). Unici ziemi tosickiej i ich walka o jedność Kościoła i polska wieś na Podlasiu. Łosice: Urząd Miasta i Gminy w Łosicach.

Dobrowolski T. 2019. Osadnictwo dorzecza górnej Tocznej w świetle źródeł historycznych. W: J. Kalaga, K. Skrzyńska (red.), Przemiany osadnicze $w$ dorzeczu górnej Tocznej we wczesnym i późnym średniowieczu (67-110). Warszawa: Archiwum Narodowego Instytutu Dziedzictwa (maszynopis).

Dunin-WąsowiczT.(2011 [1982]). Wczesnośredniowieczna sieć drożna na Podlasiu. W: A. Janeczek (red.), Drogami wczesnośredniowiecznej Polski. Studia z dziejów osadnictwa i kultury (269-282) Warszawa: Instytut
Archeologii i Etnologii PAN (= Kazimierski J. (red.). (1982). Dzieje Sokolowa Podlaskiego i jego regionu (41-57). Warszawa: Państwowe Wydawnictwo Naukowe).

Dzik M. (2011). Grobowe konstrukcje kamienne na późnośredniowiecznych cmentarzyskach w międzyrzeczu Bugu i Narwi - przyczynek do badań. W: S. Cygan, M. Glinianowicz, P.N. Kotowicz (red.), „In silvis, campis... et urbe". Średniowieczny obrzadek pogrzebowy na pograniczu polsko-ruskim (295-304). Rzeszów-Sanok: Wydawnictwo Uniwersytetu Rzeszowskiego.

Dzik M. 2012. Przemiany w średniowiecznych zwyczajach pogrzebowych $w$ międzyrzeczu środkowego Bugu i górnej Narwi ( $X I-X V$ w.). Warszawa: maszynopis w archiwum Instytutu Archeologii UW [= Dzik M. (2015). Przemiany w średniowiecznych zwyczajach pogrzebowych $w$ międzyrzeczu środkowego Bugu i górnej Narwi (XI-XV w.) 1-2. Rzeszów: Fundacja Rzeszowskiego Ośrodka Archeologicznego, Instytut Archeologii Uniwersytetu Rzeszowskiego, Państwowe Muzeum Archeologiczne w Warszawie, Muzeum Podlaskie w Białymstoku].

Gałecki Z. (2010). Ruski, lacki, litewski i inne elementy identyfikacji etniczno-językowej w nazwach miejscowości na Podlasiu. W: A. Indraszczyk (red.), Dzieje Ziemi Łosickiej. Z historii mniejszości narodowych, kulturowych i religijnych (161-177). Warszawa-Łosice: Muzeum Historii Polskiego Ruchu Ludowego.

Gałecki Z. (2014). Studia z leksykologii regionalnej i historycznej. Lublin: Wydawnictwo Katolickiego Uniwersytetu Lubelskiego.

Gałecki Z. 2019. Rekonstrukcja średniowiecznego podłoża etnokulturowego dorzecza Tocznej w świetle danych onomastycznych. W: J. Kalaga, K. Skrzyńska (red.), Przemiany osadnicze w dorzeczu górnej Tocznej we wczesnym i późnym średniowieczu (29-66). Warszawa: Archiwum Narodowego Instytutu Dziedzictwa (maszynopis).

Gieysztor A. 1967. Mazowsze w kulturze Polski średniowiecznej. Notatki Ptockie, 3-4 (43-44), 24-27.

Górska I., Paderewska L., Pyrgała J., Szymański W., Gajewski L., Okulicz Ł. (1976). Grodziska Mazowsza i Podlasia (w granicach dawnego województwa warszawskiego). Wrocław-Warszawa-Kraków: Zakład Narodowy im. Ossolińskich. Wydawnictwo PAN.

Hawryluk J. (1993). Z dziejów Cerkwi Prawostawnej na Podlasiu w X-XVII wieku. Bielsk Podlaski: Zarząd Główny Związku Ukraińców Podlasia.

Jabłonowski A. (1908). Podlasie (Województwo). W: Polska XVI wieku pod względem geograficzno-statystycz- 
nym VI (1). Źródła Dziejowe XVII (1). Warszawa: Skład główny u Gebethnera i Wolfa.

Janeczek A. (2011). Towns on the Frontier, the Frontier in Towns. Multiethnic Urban Communities in Red Ruthenia in Late Middle Ages. Quaestiones Medii Aevi Novae, 235-264.

Jaskanis D. (2008). Święck. Wczesnośredniowieczny zespót osadniczy na pótnocno-wschodnim Mazowszu. Warszawa: Stowarzyszenie Naukowe archeologów Polskich; Białystok: Muzeum Podlaskie.

Jaszczołt T. (2006). Osadnictwo lewobrzeżnej części ziemi drohickiej w XV i na początku XVI w. - okolice Sokołowa, Węgrowa i Mord. W: G. Ryżewski (red.), Sokołów Podlaski. Dzieje miasta i okolic (63-243). Białystok-Sokołów Podlaski: Urząd Miasta Sokołów Podlaski, Regionalny Ośrodek Badań i Dokumentacji Zabytków.

Jaszczołt T. (2013). Osadnictwo Podlasia nadbużańskiego w XV i początkach XVI wieku. W: O. Łatyszonek (red.), Podlasie nadbużańskie. 500-lecie województwa podlaskiego (73-168). Ciechanowiec: Muzeum Rolnictwa w Ciechanowcu.

Jusupović A. (2010). Zasięg terytorialny ziemi drohickiej w średniowieczu. Актуальні проблеми вітчизняної та всесвітньої історії. Збірник наукових працьь. Наукові записки Рівненського державного гуманітарного університету, 20, 77-80. Рівне.

Kalaga J. (1989). Wczesnośredniowieczny zespót osadniczy w Krzesku-Królowej Niwie, woj. siedleckie. Warszawa: Archiwum Instytutu Archeologii Uniwersytetu Warszawskiego.

Kalaga J. (2006). Ciałopalny obrzadek pogrzebowy w międzyrzeczu Liwca, Bugu i Krzny we wczesnym średniowieczu. Warszawa: Instytut Archeologii Uniwersytetu Warszawskiego.

Kondratiuk M. (1974). Nazwy miejscowe potudniowowschodniej Białostocczyzny. Monografie slawistyczne 29. Wrocław: Zakład Narodowy im. Ossolińskich.

Kotkowicz E. (2013). Brama na Jaćwież - rola i znaczenie Drohiczyna jako punktu etapowego w wyprawach wojennych na ziemie jaćwieskie. W: O. Łatyszonek (red.), Podlasie nadbużańskie. 500-lecie województwa podlaskiego (51-59). Ciechanowiec: Muzeum Rolnictwa w Ciechanowcu.

Krasnodębski D., Skrzyńska K., Olczak H. (2019). Badania nieinwazyjne wybranych mikroregionów osadniczych. W: A. Buko (red.), Początki chrześcijaństwa na pograniczu mazowiecko-ruskim $w$ świetle badań wybranych cmentarzysk (33-53). Warszawa: Instytut Archeologii i Etnologii PAN.
Makarski W. (1996). Pogranicze polsko-ruskie do połowy XIV wieku. Studium językowo-etniczne. Lublin: Wydawnictwo Katolickiego Uniwersytetu Lubelskiego.

Maroszek J. (2013). Dzieje województwa podlaskiego do 1795 roku. Białystok: Wydawnictwo Uniwersytetu w Białymstoku.

Mazuruk K. (2004). Stanowiska archeologiczne Bielska Podlaskiego na tle historiografii. Białoruskie Zeszyty Historyczne, 21, 133-148.

Michaluk D. (1999). Mielnik. Stolica Ziemi Mielnickiej na Podlasiu (do końca XVIII wieku). Mielnik: Urząd Gminy w Mielniku.

Mikulski J. (1969). Grodzisko pod Dzięciołami. W: J. Kazimierski (red.), Łosice 1264-1966 (81-82). Warszawa: Polskie Wydawnictwo Naukowe.

Minikowska T. (1980). Wyrazy ukraińskie w polszczyźnie literackiej XVI w. Warszawa-Poznań-Toruń: Towarzystwo Naukowe w Toruniu.

Miśkiewicz M. (1981). Mazowsze wschodnie we wczesnym średniowieczu. Warszawa: Wydawnictwa uniwersytetu Warszawskiego.

Miśkiewicz M. (1996). Wczesnośredniowieczny kompleks osadniczy w Niewiadomej $w$ województwie siedleckim. Warszawa: Wydawnictwa Uniwersytetu Warszawskiego.

Musianowicz K. (1960). Granica mazowiecko-drehowicka na Podlasiu we wczesnym średniowieczu. Materiaty Wczesnośredniowieczne, 5, 187-230.

Nalepa J. (2000). Pogranicze polsko-ruskie do połowy wieku XIV a archaiczne hydronimy i toponimy: weryfikacja ,weryfikacji”. Slavia Antiqua, 41, 27-48.

Pawlata L. (2014). Problematyka badań nad powstaniem i organizacją przestrzeni miejskiej średniowiecznego Drohiczyna. W: T. Jabłońska (red.), Małe miasta. Perspektywa archeologiczna (23-78). Lublin, Supraśl: Wydawnictwo Katolickiego Uniwersytetu Lubelskiego.

Pytasz-Kołodziejczyk A. (2018). Przemiany społeczno-gospodarcze na Podlasiu w XV-XVI w. Olsztyn: Polskie Towarzystwo Historyczne

Rauhut L. (1971). Wczesnośredniowieczne cmentarzyska w obudowie kamiennej na Mazowszu i Podlasiu. $\mathrm{Ma}$ teriały Starożytne $i$ Wczesnośredniowieczne, 1, 435656.

Russocki S. (1972). Spory o średniowieczne Mazowsze. Rocznik Mazowiecki, 4, 217-257.

Skrzyńska K. (2018). Czekanowskie Lieu de Memoire - obraz archeologiczny. W: S. Rosik, S. Jędrzejewska, K. Kollinger (red.), Hierofanie, wierzenia, obrzędy... Kultura symboliczna $w$ średniowieczu między pogaństwem a chrześcijaństwem. Materiaty $V$ Kongresu 
Mediewistów Polskich II (215-250). Rzeszów: Wydawnictwo Uniwersytetu Rzeszowskiego.

Skrzyńska K. (2019a). Wczesnośredniowieczne grodzisko w Dzięciołach. Stan i perspektywy badań archeologicznych. W: J. Kalaga, K. Skrzyńska (red.), Przemiany osadnicze w dorzeczu górnej Tocznej we wczesnym i późnym średniowieczu (144-207). Warszawa: Archiwum Narodowego Instytutu Dziedzictwa (maszynopis).

Skrzyńska K. (2019b). Dzięcioły-Łosice. Translokacja ośrodków grodowych i protomiejskich na średniowiecznym pograniczu mazowiecko-małopolsko-litewskim. W: J. Kalaga, K. Skrzyńska (red.), Przemiany osadnicze w dorzeczu górnej Tocznej we wczesnym i późnym średniowieczu (244-273). Warszawa: Archiwum Narodowego Instytutu Dziedzictwa (maszynopis).

Skrzyńska K. (2019c). „Nieznane” grodzisko w Dzięciołach, pow. łosicki. Perspektywy badawcze. Wiadomości Archeologiczne, 70, 51-62.

Skrzyńska K. (2019d). Wczesny etap chrystianizacji (XIXIII w.): pomiędzy historią i archeologią. W: A. Buko (red.), Poczatki chrześcijaństwa na pograniczu mazowiecko-ruskim $w$ świetle badań wybranych cmentarzysk (273-294). Warszawa: Instytut Archeologii i Etnologii PAN.

Skrzyńska K., Bryńczak B. (2019). Średniowieczne przemiany osadnicze i kulturowe w dorzeczu górnej Tocznej na podstawie danych archeologicznych. W: J. Kalaga, K. Skrzyńska (red.), Przemiany osadnicze w dorzeczu górnej Tocznej we wczesnym i późnym średniowieczu (111-142). Warszawa: Archiwum Narodowego Instytutu Dziedzictwa (maszynopis).

Skrzyńska-Jankowska K. (2004). Gród w Drohiczynie: centrum organizacji przestrzeni kulturowej wczesnośredniowiecznego pogranicza polsko-ruskiego. W: R. Dobrowolski, S. Terpiłowski (red.), Stan i zmiany środowiska geograficznego wybranych regionów wschodniej Polski (289-297). Lublin: Polskie Towarzystwo Geograficzne.

Skrzyńska-Jankowska K. (2014). Dorzecze środkowego Bugu jako pogranicze kulturowe we wcześniejszym średniowieczu. Warszawa: Archiwum IAE PAN (maszynopis).

Suchodolska E. (1994). Dzieje polityczne (połowa XIII - połowa XIV w. W: A. Gieysztor, H. Samsonowicz (red.), Dzieje Mazowsza do 1526 r. (177-212). Warszawa: Państwowe Wydawnictwo Naukowe.

Świętosławski W. (1997). Archeologiczne ślady najazdów tatarskich na Europe środkowa w XIII w. Warszawa: Instytut Archeologii i Etnologii PAN.
Tyszkiewicz J. (1974). Mazowsze pótnocno-wschodnie we wczesnym średniowieczu. Warszawa. Państwowe Wydawnictwo Naukowe.

Tyszkiewicz J. (2003). Geografia historyczna Polski w średniowieczu. Warszawa: Wydawnictwo DiG.

Urbańczyk S. (1968). Charakterystyka staropolskich zapożyczeń wyrazowych z języka ukraińskiego. W: S. Urbańczyk, Szkice z dziejów języka polskiego (295304). Warszawa: Państwowe Wydawnictwo Naukowe.

Wiśniewski J. (1964). Rozwój osadnictwa na pograniczu polsko-rusko-litewskim od k. XIV do poł. XVII w. Acta Baltico-Slavica, 1, 115-135.

Wilkiewicz-Wawrzyńczykowa A. (1937). Ze studiów nad polityką polską na Rusi na przełomie XII i XIII w. Ateneum Wileńskie, 11, 1-35.

Włodarski B. (1958). Rywalizacja o ziemie pruskie w połowie XIII wieku. Rocznik Toruńskiego Towarzystwa Naukowego, 61(1), 7-76.

Włodarski B. (1966). Polska i Ruś 1194-1340. Warszawa: Państwowe Wydawnictwo Naukowe.

Włodarski B. (1969). Sąsiedztwo polsko-ruskie w czasach Kazimierza Sprawiedliwego. Kwartalnik Historyczny, 76(1), 5-28.

Włodarski B. (1971). Polityczne plany Konrada I księcia mazowieckiego. Roczniki Towarzystwa Naukowego w Toruniu 76 (1). Toruń: Państwowe Wydawnictwo Naukowe.

Wojciechowski S., Sochacka A., Szczygieł R. (1986). Dzieje Lubelszczyzny. T. IV. Osady zaginione i o zmienionych nazwach historycznego województwa lubelskiego. Warszawa: Państwowe Wydawnictwo Naukowe.

Wojtowycz L. W. (2011). Walka o spadek po Romanowiczach a król polski Kazimierz III Wielki. W: J. Maciejewski, T. Nowakowski (red.), Kazimierz Wielki i jego państwo. W siedemsetna rocznice urodzin ostatniego Piasta na tronie polskim (47-66). Bydgoszcz: Wydawnictwo Uniwersytetu Kazimierza Wielkiego w Bydgoszczy.

Wróblewski W. (2001). U źródeł kasztelanii liwskiej. Wczesnośredniowieczne struktury osadnicze w dorzeczu Liwca. W: P. Urbańczyk, B. Bryńczak (red.), Najstarsze dzieje Podlasia w świetle źródet archeologicznych (205-228). Siedlce: Instytut Historii Akademii Podlaskiej.

Wysoczański W. (2002). Znaki językowo-kulturowe. Specyficzno-językowe wyznaczniki tożsamości etnokulturowej. Rozprawy Komisji Językowej WTN, 28, 4371.

Zieleniewski J. (1990). Powstanie i rozwój układu przestrzennego Bielska Podaskiego w XIV - XVIII wieku. Studia Podlaskie, 1, 47-70. 


\section{RURAL SETTLEMENT STRUCTURES AND THEIR CHANGES OVER TIME. THE EXAMPLE OF THE VILLAGE NOWOSIELEC ON THE FORMER POLISH-RUS'-LITHUANIAN FRONTIER}

\section{SUMMARY}

The medieval and early modern settlement of the Mazovian-Rus'-Lithuanian frontier-zone in the Middle Bug basin has been studied by humanists for approximately 100 years. The chronological framework of these studies has been traditionally determined by arbitrarily dated divisions of the medieval period into early and late phases. In effect, archaeologists and historians generally believe that in the 2 nd half of the 13 th century a deep settlement and demographic regress took place in the region, culturally separating the early and late phase of the medieval period. However, the latest research has successively falsified this concept.

On the micro-scale this situation is illustrated by the example of the village of Nowosielec in Łosice dist., situated in the Toczna river basin on the northern edge of the Siedlce Upland. The oldest reference to this place-name comes from 1448. Later accounts come from the 16th to the 1 st quarter of the 20th century. The term sioto, which forms the core of this place-name, is a Polonized version of the Old East Slavic word seto (village), which is recorded in letopis' chronicles written during the beginning of the 12th century. It owed its character to the simplification of the cluster $-d t$-, which took place in the east proto-Slavic dialect. In Old Polish language it corresponds to the word siodto, whose etymological meaning was taken over i.a. by the word siedlisko (settlement). Within Polish territory, the western form of such place-names is widely distributed. Those made on the Eastern Slavonic base are today registered only on the eastern and south-eastern borderlands of Poland. Nowosielec belongs to the latter group.

From the onomastic perspective, the place-name Nowosielec $=$ Nowe Sioto ('New Village') assumes the existence of older settlement, i.e., some 'stare sioło' ('old village'). The adequate opposite toponym has not been preserved in the onomastic materials of the Toczna river basin. The term Nowe Sioło, preserved in the modern cultural space as connected in its meaning to the place tradition, is the only trace of the past settlement's transformations. However, it may be assumed that the village of Stare Sioło was located nearby Nowe Sioło, but that it collapsed and slipped into oblivion.

The reconstruction of its location became feasible thanks to archaeological investigation made for nine settlement sites registered in the closest vicinity of the modern-day village. The settlement points' spatial distribution (indicated by pottery chronology) allows us to hypothesize about the local settlement's continuity with its initial phase dated to the 11th (or more likely) the 12th century. The 'old village' (stare sioło) was presumably the settlement site archaeologically recognized $800 \mathrm{~m}$ from the historical village. Its decline may be dated to the 16 th-17th centuries. This means that both villages - "old" and "new" - could have earlier functioned together for ca. 150 years, before the older one was abandoned.

The settlement's rise was probably related to the construction of the socioeconomic facilities of the nearby stronghold Dzięcioły - hypothetically identified as the pre-location centre of the region (medieval and modern Łosice). The establishment and functioning of this fortification is dated to the 12 th century and could be related to the need for the administrative and economic organization of the Rus' Halych-Volodymir Princedom's borderland. Settlement analysis has shown this process as consisting of the adaptation of structures had already existed (from the older phases of the early medieval period), but also as the active colonization of wastelands. This last form of settlement activity also left its cultural traces in the Toczna river valley, and the initial phase of older settlement points at Nowosielec may be connected to this process.

This example of the Nowosielec microregion, along with several others which appeared in the region, allow for settlement continuity analysis. In the settlement topography, local cultural landscape changes are visible in result of processes that followed this same pattern. With reference to other oecumene, the results of archaeological investigation are supported by linguistic sources, i.e., toponyms - derived from Old Eastern Slavic (Rus') apellatives and personal names. Archaeological research has shown that 
the oldest Slavic settlements of the Toczna river basin were established at least in the 8th century. They were followed by late medieval villages situated in the vicinity of those older sites. Similar changes of the spatial and chronological development of Nowosielec are very legible in regard to two neighbouring microregions: Czuchleby-Woźniki and Falatycze-Czeberaki, Łosice dist.

This study revealed that the collapse of regional early medieval settlement took place not earlier than in the 14th century. There is no confirmation for the hypothesis about settlement destabilization stipulated to have occured here in the 13th century. Moreover, at the time of the disintegration of the older settlement network, the new one was organized differently, starting to form in the 14th-15th centuries. This process was significantly influenced by this organized colonization. In effect, particularly in the western part of the region, a compact network of petty nobility villages was established, located mainly on contemporary wastelands situated on natural borders of older early medieval microregions. The latter changed their original localization and were rebuilt in other, hitherto unsettled places, but still located within the range of the already crystalized oecumene. At this stage of research it is difficult to determine the character of the abandonment of older settlements. Was it a long-term process or an episode that can be chronologically well defined by special socio-cultural circumstances? The example of the presumably temporal coexistence of the "new" and "old" villages at Nowosielec shows that at least some of the "older" ones survived and the process of their long-term collapse took place gradually, possibly in connection with the steady decrease of their demographic potential.

Otrzymano (Received): 11.05.2020; zrecenzowano (Revised): 7.09.2020; zaakceptowano (Accepted): 18.09.2020

\section{Adresy Autorów:}

Dr hab. Zygmunt Gałecki

Akademia Pedagogiczno-Humanistyczna

im. Tarasa Szewczenki w Krzemieńcu, Ukraina

e-mail: galecki.zygmunt@wp.pl

(iD https://orcid.org/0000-0001-8671-575X

Dr Katarzyna Skrzyńska

Ośrodek Interdyscyplinarnych Badań Archeologicznych

Instytut Archeologii i Etnologii PAN

Al. Solidarności 105

00-140 Warszawa

e-mail: kasiaskrzynska@tlen.pl

(iD https://orcid.org/0000-0001-5606-1177 